\title{
Uddrag af dagbogsblade fra Tønder under den tyske besættelse
}

\author{
Af Morten Bredsdorff
}

Som forstander for Tønder Statsseminarium 1937-47 førte jeg i besættelsesårene 1940—45 med mellemrum dagbog over begivenheder, der berørte seminariet og forhold i min nærmeste kreds. Desværre ikke regelmæssigt; på grund af hårdt arbejdspres og til tider noget besværlige forhold er der ret store lakuner i mine dagbøger.

De her meddelte dagbogsblade er til gengald alle nedskrevet umiddelbart efter de omtalte begivenheder, dels på grundlag af noter $\mathrm{i}$ lommebog undervejs, dels - det gxlder f. eks. møderne med den tyske kommandant $\mathrm{i}$ Haderslev og på Tønder amtshus, april 1945, - efter forceret nedkradsning med blyant under selve mødet, idet jeg lod, som om jeg tog referat af de trufne beslutninger. Disse blade blev derefter renskrevet samme aften eller nat, hvad bl. a. kan ses af papirets kvalitet og skriften. Jeg har siden intet tilføjet og kun strøget enkelte rent private sætninger inden offentliggørelsen i *Sønderjyske Årbøger «.

Som almindelig oplysning kan tjene, at såvel undervisningsminister Jørgen Jørgensen ${ }^{1}$ som hans efterfølgere og seminariernes chef under hele besættelsen, departementschef A. Barfod, under alle tjenstlige besøg $\mathrm{i}$ ministeriet indskærpede, at seminarieforstanderens største ansvar $\mathrm{i}$ Tønder var at bevare statsseminariet og dets øvelsesskole - i hine år Tønders eneste danske folkeskole - intakt så længe som overhovedet muligt, at undgå unødige provokationer og ikke udsætte det danske skolevæsen for tysk indblanding. Det samme blev jævnligt fremhævet af amtmand, grev O.D. Schack, ${ }^{2}$ amtsskolekonsulent Nicolai Svendsen ${ }^{3}$ og andre ledende sønderjyder i Tønder og Vestslesvig. 
Ved hjælp af et enestående godt samarbejde i seminariets lærerkollegium lykkedes det at hindre adskillige forsøg på indgreb $i$ besættelsens første fire år. Men da besættelsesmagten i 1944 slog i bordet og krævede plads $\mathrm{i}$ den ene af Tønders store skolebygninger, enedes rektor Randrup ${ }^{4}$ og jeg om hellere at overlade den tyske kommandant gymnasiets noget mindre bygning og samle hele det danske skolevæsen i statsseminariets mere rummelige lokaler. 1944/45 måtte vi derfor huse såvel seminariets og øvelsesskolens egne elever som gymnasiet og mellemskolen, en ingenlunde let opgave. Men den løstes ved godt samarbejde nogenlunde, indtil de tyske myndigheder i marts 1944 næsten uden varsel beslaglagde hele statsseminariet som krigslazaret, elevhjemmet $\gg$ Klosteret « endda som epidemihus. Ved hjælp af storslået gxstfrihed fra de danske tønderborgeres side lykkedes det at få anbragt samtlige danske elever i større og mindre lokaler over hele den lille by, øvelsesskolens børn dog i restaurant "Schweizerhalle«, som vi på grund af dens beliggenhed omdøbte til "Riberhusskolen«. Under sådanne forhold gennemførtes både lærereksamen og studentereksamen i foråret 1945.

I hårdt medtaget tilstand blev statsseminariets bygninger frigivet sidst $\mathrm{i}$ august 1945, hvorefter en større istandsættelse fandt sted.

Noterne vil i øvrigt meddele de nødvendige, kortfattede historiske oplysninger.

\section{I}

Sommer og efterår 1943.

1. august. Schweiz's frihedsdag. Vi fejrede den i Faurholms have, Nalmose, ${ }^{5}$ med et lille skuespil, "Wilhelm Tell «, som Elisabeth og Thomas opførte. Om aftenen et mægtigt tordenvejr, så de måtte gentage det lille spil for Faurholms inde $\mathrm{i}$ stuen, mens tordenvejret drev ud over Lillebælt og Østersøen.

2. august. Med middagsfærgen fra Mommark; Friedy til Ollerup, ${ }^{6}$ jeg til Liselund, ${ }^{7}$ vi skiltes $i$ Ringe for at mødes dér igen i morgen på hjemvejen. Ret sen ankomst til Liselund. Samtale med den ældgamle Niels Dael og hans hustru. 
3. august. Luftalarm i nat kl. ca. 4. Ret stærk skydning og dumpe brag i sydlig retning. Jeg var urolig over at være borte fra børnene og stod op. Sov dårligt i nat. Jeg talte kl. 13: »Hvordan kan jeg under disse forhold bedst gavne land og folk?* (Om faren ved det blinde had og de ukontrollerede stemningsbølger; på langt sigt; vi skal holde vor kurs og vore løfter, uanset hvad andre gør ved deres). Niels Dael takkede varmt. Så afsted med bil til toget, i Ringe mødtes jeg med Friedy, truende uvejr mellem Faaborg og Mommark, men vi nåede dog hjem $\mathrm{i}$ god behold på tandem henad midnat.

5. august. Op kl. 4. Øsende regn, morgenmad og regntøj, afsted til Sønderborg for at nå 5,20. Undervejs stilner regnen noget af, jeg kommer rettidigt og nogenlunde tør til stationen, og når Tønder Øst kl. 7,45. Tønders 700-års jubilæum, blomster og flag overalt, kl. 8,30 en gammel postrytter gennem gaderne, kl. 9 festgudstjeneste i Kristuskirken. Da vi er færdige og vil gå, hvisker politimester Martensen-Larsen ${ }^{8}$ til politimester Brix $^{9}$ og et par andre uniformerede embedsmæend, at de er nødt til at blive også til den tyske gudstjeneste, ministeren bliver også. Dommeren ${ }^{10}$ ser på mig: "Jeg går sgu min vej - «. Vi følges med de andre ud af kirken, udenfor træffer jeg bl. a. museumsdirektør Mackeprang, vor elskværdige redaktør fra "Tønder gennem Tiderne «, 11 som udkommer i dag. Jeg får ham, noget modstræbende, med til receptionen på rådhuset kl. 11 .

Kl. 11. Receptionen er af praktiske grunde forlagt til amtshusets store sal. Her modtager borgmester ${ }^{12}$ og byråd gratulationer på dansk og tysk; han svarer roligt og værdigt, ikke uden variationer og altid på dansk, det hele får et meget pæent forløb og ender med et glas vin. K1. 12,30 jubilæumsfrokost på Hotel Tønder. Borgmesteren indleder med hyldest til kongen, og der synges "Kong Christian« 1. vers, skønt flere tyskere ser noget misfornøjede ud. 3 timers spisen og drikken. Ministeren taler; officiel lykønskning; nogle klare ord om dansk retspleje; alle lige for loven i Danmark, alle skal behandles ens, det fraviger vi ikke. Gid livet $i$ Tønder fortsat må trives $i$ fordragelighed mellem de to nationaliteter. Amtmanden taler, klogt, varmt og forsigtigt, om grænsebyens særlige kår. De andre sønderjyske borgmestre taler kort. Så kommer de tyske taler; vel forberedt, oratorisk unægtelig bedre end adskillige af de danske præstationer, hvoraf flere særlig hen mod slutningen var rene tilfældige improvi- 
sationer. Først lærer Glæser: ${ }^{13}$ historisk om Tønder, som »eine Stadt der Bürgerschaft $\kappa$, om pietisme og social hjxlpsomhed, om Brorson og Schrader, så - overraskende - om $»$ Die Politik der nationalen Versöhnung, die Klosterpolitik des Cornelius Appel —«. Derefter følger tidl. folketingsmand pastor Schmidt: ${ }^{14} \mathrm{Om}$ menneskets vækst, fra hjem til hjemstavn, videre til borgerskab og landsmandsskab, endnu videre, win die grosse Völkerfamilie hinein - ich will nicht propagandieren, aber die Geschichte will es, es kommt eines Tages - durch Leiden und Streit ein hohes Ziel, das friedliche Zusammenleben der Völker als Brüder. Ich habe es in meiner Politik immer angestrebt.* - Så pastor Rühmann ${ }^{15}$ Om dagens begyndelse med gudstjeneste $\mathrm{i}$ Tønders ånd, om det åndelige livs kår, om $\gg$ die freisinnigen dänischen Kirchengesetze«, og de gode kår, som disse skænker også den tyske menighed her. Man kneb sig $i$ armene, en forbløffende ny tone. Dog bemærkedes, at Elholm ${ }^{16}$ ikke talte, og nxppe gad rejse sig, da der indløb telegram fra kronprinsen. Der fulgte flere, ikke særlig betydelige taler, den gamle dommer Gjessing gav Tønder-minder til bedste, og en anden Tønder-dreng, Friedrich Andresen, sekunderede ham. Mod slutningen blev tonen noget støjende, øl og snaps gjorde deres virkning visse steder, indtil grænsegendarmeriets oberst, Paludan-Müller, ${ }^{17}$ Graasten, rejste sig og holdt den korteste tale: $"$ Det er meget godt med al den tale om naboskab og fordragelighed. Der er bare det $\mathrm{i}$ vejen, at det er odelagt for de forste 200 år af det, som skete den 9. april!! - Hyssen og almindelig uro, protest fra tyskerne, nogen flovhed blandt danskerne. Borgmesteren måtte redde situationen ved at beklage den faldne udtalelse, der ikke hørte herhen; vi har kunnet leve som naboer $i$ fordragelighed, vi bør fremdeles kunne dele Vorherres gaver. "Velbekomme! « - Ved udgangen spurgte ministeren mig, om jeg kendte PaludanMüller, og tilføjede selv: "Han er jo tosset, han må væk! « Opbrud i nogen uorden, en del fortsatte i restaurationen, hvor det vist nok gik ret drabeligt til mellem enkelte ophedede hoveder, dog endte alt vist $\mathrm{i}$ brændevinsforsoning. Jeg gik min vej og fulgtes ned til seminariet med dr. Mackeprang; vi var forundrede og på en måde grebne af de tyske taler - »men Orel $^{18}$ er faldet $i$ morges «, sagde Mackeprang, "Orel er faldet!! « Vi var enige om, at den sidste tale burde være undgået, den var dum og taktlos og bragte os danske i defensiven. Derimod havde det været værdigt, om vi $i$ tavshed 
havde påhørt de tyske taler med deres fredstilbud; lad dem nu snakke, vi har et åbent sår, som vi foreløbig ikke taler om. Solskin i seminariegården, hvor Mackeprang og jeg stod og talte og tog afsked.

Jeg tog med 17,40 til Tinglev; i toget traf jeg amtslægen, han var spydsk: "En forloren fest « — "uxrlighed og tomme ord det hele«, "burde aldrig have fundet sted o. s. v.« Måske har han ret.

Fra Tinglev cyklede jeg $i$ en stille, ret mild sommeraften over Graasten, Dybbøl, Sønderborg, Fynshav til Nalmose; hjemme ved 22-tiden efter en ejendommelig og indholdsrig dag.

Onsdag den 25. august. På cykel til Ellehus efter indbydelse af Erik Appel, ${ }^{19}$ der ville samle grænsekonventet. En del af omegnens lærere, præster og enkelte landmænd. Appel gav en redegørelse for den senere tids begivenheder i Esbjerg og Odense, indkaldelsen af samlingspartierne, forhandlingerne om det sidste opråb til befolkningen og ønskede en drøftelse af befolkningens syn på sabotagen og dens forhold til rigsdagen. Flere gav udtryk for voksende sympati med aktivisterne og kritiserede rigsdagen, der skulle være ved at miste sit tag i befolkningen. Andre - herunder også jeg - udtalte uvilje mod, at dansk ungdom af en uansvarlig propaganda lod sig drive til krigsmæssige handlinger, der stred mod den holdning, vi engang havde valgt at indtage, og fandt det besynderligt, at befolkningen ville rende fra den rigsdag, som den 23. marts var blevet valgt med så overvældende tilslutning. Et ret klart billede af en stemningsbølge i vækst - det var mit indtryk af drøftelsen i dagligstuen og haven på Ellehus.

Fredag den 27. august skulle jeg afrejse til studentermødet i Gerlev. Meget betænkelig, truende strejker, måske generalstrejke, uro i flere byer, Aarhus og København bl. a. Konfererede med politimesteren, der mente, at noget snart kunne ske, men dog næppe så hurtigt, at en 2 dages rejse ikke kunne gennemføres. Ing. Westh'0 fandt også, at jeg burde rejse for at få indtryk af mødet og lidt flere oplysninger.

Fredag $\mathrm{i}$ det store frikvarter gav Eskildsen ${ }^{21}$ oplysninger fra Dansk Samråds møde i Aabenraa. Jeg bad ham være min stedfortræder, og vi tog afsked, han rystede min hånd hjerteligt og sagde ironisk-patetisk: "På gensyn, måske først til fredsslutningen, eller når vi ser forstanderen igen *. 
Afrejse med 11,54. En rolig rejse, stærk forsinkelse i Fredericia, en enerverende langsom fart over Fyn med umotiveret standsning $i$ Gelsted, hvor sirenen tudede (kl. ca. 16). Mange på færgen, traf gamle skolekammerater, Hans Tholstrup, biografdirektør i Middelfart, og Knud Tholstrup, direktør for Dansk Gasflaskefabrik; sidstnævnte kom fra Aarhus og skildrede indtryk af generalstrejken med talere på havnen. Jeg nåede Slagelse med en times forsinkelse kl. 20, på hvilket tidspunkt jeg skulle tale i Gerlev (8 km fra Slagelse). I lob ud at finde en bil - der var kun en enkelt - hvis 'chauffør underholdt med rygter om rigsdagens indkaldelse, uroligheder i København, strejketrusler fra B. og W., demonstrationer mod politimesteren i Slagelse m. m., som jeg dog ikke tillagde videre betydning. På Gerlev Idrætsskole hjertelig modtagelse af professor Niels Nielsen, en kort samtale med en skare journalister, der ville have hovedtræk af mit foredrag på forhånd for at få aftenforbindelse med deres københavnske morgenblade. Så et glas mælk, og derefter talte jeg for en talrig, meget ungdommelig og særdeles begejstret studenterskare om Forbundsstaten Schweiz«. Ved det påfølgende kaffebord mærkede jeg, at prof. Niels Nielsen var noget åndsfraværende, og han angav selv grunden. Den danske stemme fra London havde bebudet en tale til Gerlevmødet kl. 22, hvor prof. Mogens Fog ville tale til studenterne, og han ønskede ikke at støtte dette foretagende. Han foreslog studenterne at vise dem sin film fra $\mathrm{Ka}$ relen, hvor han havde gjort en rejse $i$ juni, lidt uenighed opstod om tidspunktet, og ledende senior måtte bøje sig for de unges krav: først kl. 22,30. Lidt før kl. 22 gik alle studenterne ud af spisesalen til en radiostue, senioratet og jeg blev siddende, og her hørte jeg mange ildevarslende oplysninger. Sxrlig foruroligende telefoniske oplysninger om visse troppebevægelser fra den ydre mod den indre by, tanks foran gesandtskabsboligen ved Kastellet, formodninger om en forestånde yderst alvorlig krise. Efter lysbillederne fra Karelen (Mogens Fog havde ikke talt, det var det velkendte bulder fra de unge mennesker derovre i stedet), samledes senioratet i Krogshedes dagligstue, og vi drøftede stillingen til kl. 1. Prof. Nielsen, prof. Thorkild Kristensen, Aarhus, og jeg var betænkelige ved, at situationen spidsede sig sådan til, at arbejdere og befolkning syntes at desavouere deres egne tillidsmænd, og vi var overbeviste om, at en generalstrejke ville vi uvægerlig tabe. Jeg overvejede, om jeg skulle søge at 
nå en postfærge i nattens løb, men det var usikkert, om den gik og Thorkild Kristensen og jeg gik så til ro med det håb, at vi vel nok på en eller anden måde slap over Storebælt.

Lørdag den 28. august. Med bil til Slagelse, hurtigtoget fra København næsten rettidigt og meget fyldt, som sædvanligt. I Korsør råbte højttaleren på en assistent ved statsradiofonien; han skulle straks afbryde sin rejse og vende tilbage til Kobenhavn. Nå ja, det behøvede jo ikke at angå os andre, selv om der råbtes så højt $i$ et lidt usædvanligt anliggende. Undervejs en god samtale med den besindige professor Thorkild Kristensen, der var bekymret over landsmænds ringe realitetssans, så snart det gjaldt udenrigspolitik. Vi var på så mange felter enige, også om den vanskelige udvikling, der forestår, om der skal gro nye liberale tanker frem $\mathrm{i}$ landet.

Vi skiltes i Nyborg, og rejsen var i øvrigt uden sensationer. I Fredericia overhørte jeg en samtale mellem nogle handelsrejsende om strejken i Aarhus, den syntes at være grundig og omfattende.

Jeg ankom over Bramminge til Tønder $\mathrm{H}$. uden særlige oplevelser. Toget var inde ca. 19,30, og på banegården ventede Friedy og Elisabeth mig, vi var alle tre glade over, at denne rejse var vel overstået. Da vi nåede hjem, var overlærer $\mathrm{Brahm}^{22}$ i telefonen; han havde besøg af rektor Randrup, og de ville omgånde tale med mig om vigtige ting. Jeg bad om at måtte spise lidt forst, da jeg intet havde fået siden færgen, men allerede 10 minutter senere indfandt de to herrer sig i min stue. Rektor Randrup berettede, at han gennem politimester Martensen-Larsen, Aabenraa, havde sikker efterretning om, at et tysk ultimatum var udløbet om eftermiddagen, at tyskerne havde styrtet regeringen og overtaget magten, og at vi snart ville få følgerne at mærke. Hans første overvejelser gjaldt lønudbetalingen den 1. september, og han foreslog, at seminariet og statsskolen allerede søndag søgte at formå deres bankforbindelser til på forhånd at udbetale lærerne septemberlønnen. Jeg tøvede, dels under indtryk af de stærke begivenheder, dels fordi jeg mente, at vi frem for alt ikke skulle foretage noget usædvanligt, eller noget der kunne bidrage til at forøge uroen; endelig var det imod loven at udbetale før den 1. Det sidste punkt ville rektor med god samvittighed sætte sig ud over, sagde han, og vi drøftede det frem og tilbage. Jeg mente, at dersom disse efterretninger var sande, ville der antagelig ske lukning 
af bankerne, i øvrigt ville man næppe i første omgang forholde embedsmænd deres løn. Vi skiltes med aftale om at holde forbindelsen vedlige de næste dage.

Min heldige hjemrejse havde givet mig en vis sjalero, så jeg foretog mig foreløbig intet. Desuden er vi efterhånden så vant til disse nervekriser, at man hellere må »wait and see«. Kl. 22 ringede bagermester Thorvald Petersen, ${ }^{28}$ at rygterne vist var overdrevne, det danske svar var sendt til Berlin, og søndagen ville formodentlig bringe en afklaring. Som det skulle vise sig, var dette ikke rigtigt, men det var et fortrinligt sovepulver, og vi sov godt natten til søndag.

Søndag den 29. august. ${ }^{24} \mathrm{Vi}$ vågnede ret sent $\mathrm{i}$ strålende sol. $\mathrm{Da}$ jeg kom ned, var seminarielærer Gravgaard ${ }^{25}$ kommet. Han meddelte mig ret foruroliget, at regeringen var gået, at tyskerne havde taget magten og allerede patruljerede Tønders gader, samt at Claus Eskildsen var arresteret af tyskerne tidligt $i$ morges. Vi ilede til radioen og hørte det meste af det bekendte "opråb «, der skulle oplyse om, hvad der var sket. Så vidste vi så meget. Kl. 10,45 kom folketingsmand Erik Appel og hans hustru indenfor hos os, de ville i kirke i Tønder og $\mathrm{i}$ øvrigt drøfte stillingen med os. Appel vidste i øvrigt ikke meget mere end vi andre og var ikke klar over, om han var rigsdagsmand eller ej. Appels og vi fulgtes til kirke, der var ikke særlig mange, men tydeligt nok lagde folk mærke til, at Appel var på fri fod. Rygterne havde åbenbart god fart. Pastor Magle ${ }^{26}$ holdt sig til teksten og lod sig, heldigvis, ikke forlede til improvisationer i dagens anledning. Og salmerne blev sunget med stor kraft. Efter prædikenen strømmede de fleste ud af kirken, vi blev en hel lille skare udenfor, indtil vi indså faren, da tyskerne passerede torvet, og spredtes.

Derefter samledes en lille skare embedsmænd uopfordret $i$ vore stuer. Rektor stod og ventede os, da vi kom fra kirke, Hans Andersen, Kongsbjerg, ${ }^{27}$ og hans kone fulgte med ind, så kom Appels, derefter dommer Stegmann og endelig ingeniør Westh. Vi søgte gensidigt at orientere hinanden. Hvilken stilling indtager kongen? Ministeriet? Rigsdagen? Hvad skal embedsmændene nu gøre? Det sidste gav anledning til ret livlig drøftelse. Rektor indtog et ret aggressivt standpunkt og syntes $i$ tvivl, om man skulle gå $i$ arbejde næste dag. Dommer Stegmann: Hvad vil De gøre, rektor, hvis Deres elever strejker? - Rektor: Det tror jeg ikke, de gør! - Dommeren: Hvad 


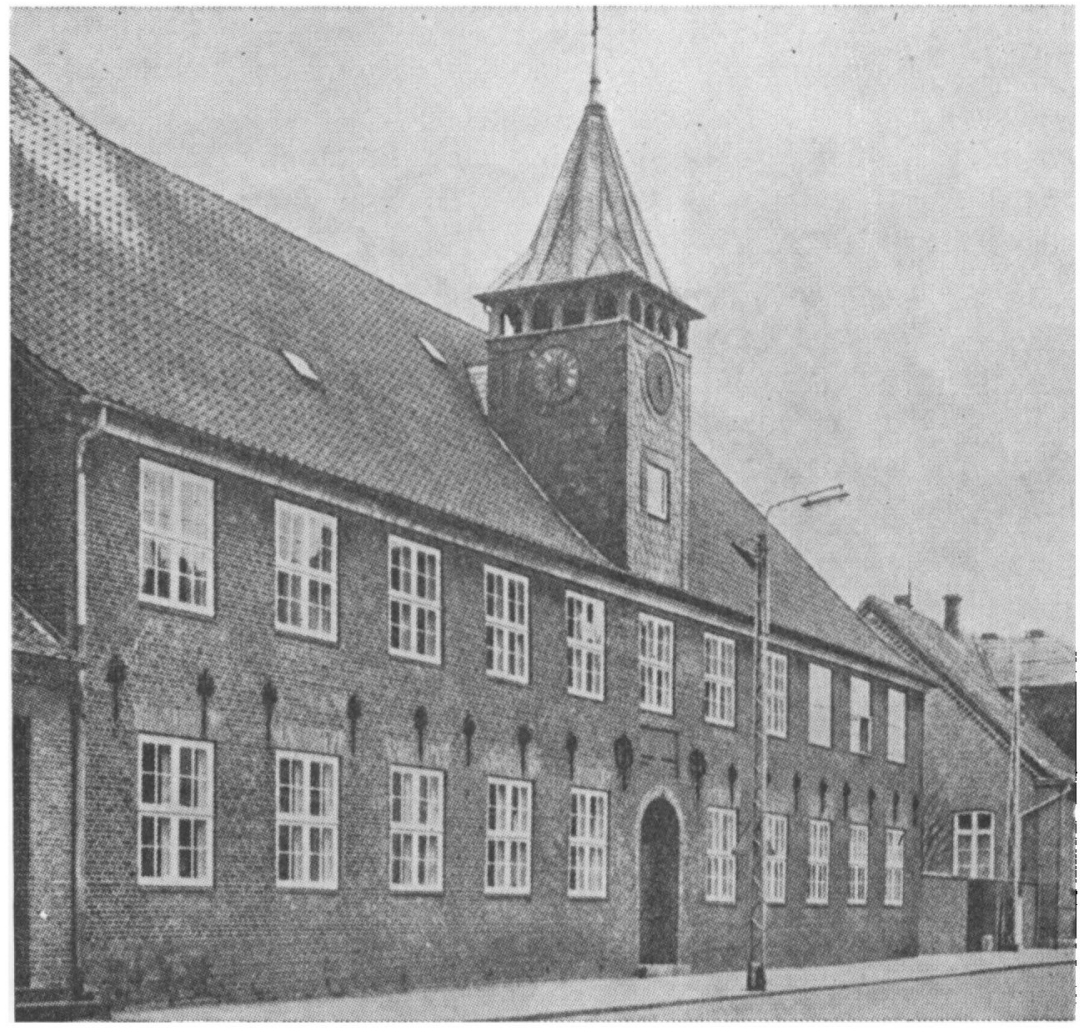

Helligaindshospitalet i Tonder. Fra slutningen af trediverne en del af seminariet, bl. a. rummer det seminariets bibliotek. I baggrunden skimtes forstanderboligen.

gør De her på seminariet? Vi vil passe vort arbejde, så længe det overhovedet er muligt - hvem gavner vi med at løbe fra det? Dommeren: Jeg går sgu også $\mathrm{i}$ retten $\mathrm{i}$ morgen, jeg skal dømme en hjemmetysker, der har solgt ulovligt til værnemagten, det kan blive helt fornøjeligt! Ingeniør Westh: Vi kan i hvert fald ikke begynde med arbejdsnedlæggelser. Hans Andersen: Det er helt rigtigt. Embedsmændene skal blive ved, så længe de bare kan få lov. Men hvad skal vi gøre ved gidslerne? Det blev nu oplyst, at foruden Eskildsen var dr. Dahl ${ }^{28}$ og provst Schülein ${ }^{29}$ arresterede af tyskerne. Hans Andersen slog fast, at vi måtte være helt solidariske med vore fangne landsmand, protestere og arbejde på deres befrielse ad alle kanaler. 
Han opfordrede Appel til at benytte den tillid, han faktisk nød hos hjemmetyskerne, til at få disse mænd befriet. Appel var meget tilbageholdende, ville ikke foretage sig noget, syntes i det hele taget en smule uklar og usikker i denne uvante situation. Det besluttedes så, at Appel og Hans Andersen som repræsentanter for den vestslesvigske befolkning skulle gå til borgmester Paulsen nu straks og nedlagge en protest, som borgmesteren skulle viderebringe til kommandanten.

Derefter gik dommer Stegmann, og kort efter besteg Appel og Hans Andersen deres cykler for at tage ned til Landmandsbanken og træffe borgmesteren. Et forsøg på opringning til hans nummer blev afvist af centralen: Telefonering er forbudt! Lige efter, at de var gået, ringede telefonen: Det er politimesteren. Jeg har lige hørt af dommeren, at der sidder en lille kreds hos Dem. Hvis den samme kreds stadig er tilstede, vil jeg gerne komme straks for at sige dem et par ord.

Ingeniør Westh fløj så afsted og indhentede Appel og Hans Andersen ved Landmandsbanken, de kom alle tre tilbage, og et øjeblik efter kom politimesterens bil ind $i$ Vidaagade. Han ankom $i$ uniform, og det vakte en smule opsigt, da han gik ind $i$ vort hus. Kort $\mathrm{i}$ forvejen var en patrulje med de lilla plakater og ledsagende tyske drenge gået igennem den lille gade.

Politimesteren: Jeg hørte, at disse herrer var samlet her. Derfor vil jeg gerne benytte lejligheden til at give Dem en fremstilling af, hvad jeg har oplevet i dag.

Kl. lidt før 4 i morges ringede min telefon. Det var dr. Dahl, der sagde noget om, at man ville arrestere ham som gidsel, at han protesterede, men så blev der afbrudt, vistnok ved at røret blev revet fra ham. Jeg hørte ikke mere. 15 sekunder efter ringede det på min egen dør. En tysk officer bad mig følge med til kasernen, kommandanten ville gerne tale med mig. Jeg fulgte med i bilen og blev straks ført op til kommandant Onnen, med hvem jeg havde haft adskillige tjenstlige konferencer i den senere tid - en ret skikkelig mand, vistnok tandlæge i det civile liv. Han fortalte mig, at der var erklæret undtagelsestilstand fra kl. 4, og spurgte, om jeg ville medvirke fortsat til ordenens opretholdelse. Jeg svarede, at for befolkningens skyld var jeg rede til at medvirke til ordenens opretholdelse, forsåvidt og så længe som dette var foreneligt med mine pligter som 
dansk embedsmand og $\mathrm{i}$ overensstemmelse med de hidtil givne danske love, samt min ed på at ville holde grundloven. Til udførelse af dødsstraf ville jeg ikke under nogen form medvirke. Kommandanten svarede, at dette var tilstrækkeligt. Jeg tilføjede, at skønnet over, når disse forudsætninger ikke længere eksisterede, beroede hos mig selv. Han bad mig selv sige til, når jeg ikke ville længere. Derefter nedlagde jeg en energisk protest mod anholdelsen af gidsler, om hvilken jeg var blevet underrettet af den ledsagende officer. Han beklagede, hvis der var sket fejltagelser; han handlede efter ordre fra Copenhagen og kunne intet ændre. -

Med den største interesse lyttede alle tilstedeværende til politimesterens beretning. Hans holdning blev anerkendt fra alle sider, ikke mindst af Hans Andersen, hvad der åbenbart også glædede politimesteren, der af let forstålige grunde syntes at trænge til forbindelse med befolkningen umiddelbart efter denne vanskelige affære. Jeg takkede ham, fordi han ville komme og give os en førstehåndsskildring, og tilføjede at hans principielle holdning kunne vi andre embedsmænd slutte os til. Derefter tog politimesteren afsked.

Vi drøftede sagen endnu en stund. Da politimesteren havde henstillet, at man ventede med protesten gennem borgmesteren, lod vi denne sag ligge foreløbig. Vi skiltes, enige om at søge fornøden personlig forbindelse i den nærmeste tid.

Efter middag kom amtsskolekonsulent Svendsen på et kort besøg. Han var i gammeldags, sønderjysk kamphumør. Han havde fundet amtshuset besat af 10 mand, havde dundret med sin stok i gulvet for dem, forbudt dem adgang til sit kontor, og da de bad om en vagtstue, havde han med særlig fornøjelse vist dem ind $\mathrm{i}$ den tyske konsulent Elholms kontor. "Aber seine Papieren rühren Sie auch nicht! «, hvilket de høfligt tog til efterretning. Han ved, hvordan man bør optræde og behandle disse folk. Greven var meget mismodig, sagde Svendsen. Hans gamle tvangstanke om flytning af grænsen til Kongeaaen var livet stærkt op igen. Som adelsmand følte greven sig stærkt påvirket af kongens holdning og hele formentlig ufrie stilling. Svendsen havde kraftigt opfordret ham til at fortsætte. "Selv bliver jeg i min kontorstol, til de bærer mig ud!« - Vi var enige.

$\mathrm{Da}$ jeg $\mathrm{i}$ dagens løb fik en del forespørgsler fra lærerne, bad jeg alle seminariets lærere komme hen til mig privat kl. 16,30, hvor jeg 
fortalte dem, hvad jeg havde erfaret. Der var almindelig enighed om, at vi roligt skulle fortsætte arbejdet for vore elevers skyld, og almindelig harme over arrestationerne, selv om vi ikke overraskedes over Eskildsens skæbne under disse forhold.

Da lærerne gik, kom Thorvald Petersen og grevinde Moltke ${ }^{30}$ på besøg for at få lidt oplysninger. "Vi står skidt $\mathrm{i}$ det«, sagde Th. P., "vi er rendt fra vore tillidsmand, det er ingen god begyndelse. I $1918 \mathrm{kom}$ vi hjem med våben, men vi skød ingen tyske soldater, nu er det danske folk på vej ud i en uansvarlig krigsførelse, bl. a. på grund af hele den agitation fra Christmas Møller og de andre herrer, der sidder $\mathrm{i}$ London uden føling med landet og vil dirigere det heleк.

Inden Th. P. var gået, kom pastor Magle; da jeg i delvis tilslutning til Th. P. ytrede en beklagelse af det uklare $i$ hele situationen, særlig hvis krigen, hvad der var sandsynligst, endnu skulle vare længe, udbrød pastor Magle, at dette var en klaring, som ikke havde noget med logik at gøre, men var et spontant udbrud af folkesindet.

En anstrengende, men indholdsrig og værdifuld dag; det gjorde alligevel godt at tale med så mange ansvarsbevidste mennesker.

I aften efter mørkets frembrud dundredes der på vore vinduer; jeg troede, det var bøller, og lod som intet. Så buldrede det løs igen, og der råbtes. Jeg gik ud på gaden, der stod en patrulje, som råbte, at vinduerne mod gaden skulle lukkes. Vel, men det havde vi ikke fået at vide. Lidt efter blev der skudt længere oppe i Østergade, vistnok efter et belyst vindue. Så besluttede vi at gå i seng.

Mandag den 30. august. Ved morgensangen gav jeg eleverne en kort orientering om gårsdagens begivenheder; vi sang: Alt står i Guds Faderhånd! og gik så, som den 9. april 1940, roligt til vort arbejde på det danske statsseminarium. I dagens løb bragte Carsten Eskild$\operatorname{sen}^{31}$ hilsen fra sin fader, hvem familien havde tilladelse til at besege.

Torsdag den 2. september. Friedys fødselsdag. Kl. 14 tog vi en lille cykeltur på tandem ud til kasernen, da jeg gerne ville besøge Eskildsen for at drøfte fagene med ham. Friedy ventede udenfor. I vagten måtte jeg opgive navn og ærinde, tidspunktet blev opskrevet, og en vagt fulgte mig til Standortältestes kontor. "Wer sind Sie? Was wollen Sie? $\times$ o. s. v. Ledsaget af vagtpost og officer skred jeg 
over gården, mødte fru provstinde Schülein, der ligeledes var solidt beskyttet; vi hilste hjerteligt, mens vagterne stod ret bag os. Jeg kom op på 1. sal, og Eskildsen blev kaldt ud i gangen, hvorpå vi fik lov at være ene $\mathrm{i}$ et tidligere løjtnantværelse med bord, seng, boghylde og radio. På Eskildsens øjne kunne jeg se, at det hele havde gjort stærkt indtryk; han kendte prøjserne fra gammel tid. Men han var rolig og ligevægtig, da vi kom i samtale. Først om fagene, psykologi og tysk, det første skulle jeg overtage, men han ventede at komme ud måske allerede søndag, grev Schack havde været der og mente bestemt, de ville blive losladt snarest; der var kludret med disse anholdelser. "Forstanderen er vel ikke vred på mig? « sagde Eskildsen, »det er ikke for noget, jeg har gjort. Jeg er her som gidsel, det står på arrestordren « (hvad der er rigtig nok, jeg har selv set en afskrift "Als Geisel «).

Jeg svarede, at jeg naturligvis ikke var vred, skønt han og jeg jo ikke altid havde været enige om, hvad der under disse forhold var klogt og ret (vor drøftelse i oktober 1942), men at forholdene her igen havde vist sig så meget større og stærkere end al menneskelig beregning. Det gav han mig ret $\mathrm{i}$ (fru Eskildsen har senere givet mig ret $i$, at han ikke længere havde regnet med sandsynligheden af arrest, da der intet var sket efter 9. april 1940). Inden vi skiltes, tog han mig med over gangen og ind $i$ det fælles opholdsrum, hvor jeg hilste på provsten og dr. Dahl - dommer Stegmann var på besøg. - Så tog jeg afsked: "På snarligt gensyn!« Under militær ledsagelse og heftig øvelsesskydning omkring kasernen gik jeg atter ud til Friedy, der imens havde truffet provstinden og talt med hende.

Søndag den 5. september. Om formiddagen ringede fru Hans Andersen, Kongsbjerg, og bad os gøre dem et eftermiddagsbesøg. I dejligt septembervejr cyklede vi på tandem med Thomas bag på og Lisbeth på egen cykel ud forbi kasernen - visitation på landevejen af vagtposter, hvad der $\mathrm{i}$ høj grad interesserede børnene - over Abildgård til Kongsbjerg. Hans Andersen mødte os på vejen. En hyggelig og god eftermiddag. Vi samtalede om gidslernes skxbne; H. A. havde opsøgt borgmesteren og talt indgående med grev Schack, var utilfreds med Appels lidt passive holdning. Foreløbig næppe noget at gøre. Vandring ud til Rugbjerg med stor udsigt over Kongens Mose og Vestslesvig. Vi drøftede flagning; jeg holdt på, at vi 
skulle undlade flagning nu, da kongen var fangen og staten lammet helt. H. A. mente, vi skulle opmuntre hinanden med flagning den 26. september. Vi blev enige om, at der måtte en fælles parole til $i$ begge tilf $æ l d e$. Det var rart at tale med denne solide, vestslesvigske bonde.

På hjemvejen mødte vi ved 18,30-tiden fru Eskildsen og hendes søn ved kasernen, de kom fra besøg. Der er endnu ingen tegn til løsladelse.

Tirsdag den 7. september. Efter skoletid kl. 14 kom lærerinde frk. Horsbøl ${ }^{32}$ ind på kontoret; hun ville gerne, fortroligt, meddele mig, at hun gennem en bekendt havde hørt, at man på den tyske skole ventede indkvartering i de nærmeste dage, og at man der regnede med, at måske både seminariet og statsskolen ville blive taget af tyskerne. Det var vel ikke absolut overraskende, men meget foruroligende. Jeg sprang på cyklen for straks at opsøge borgmester Paulsen. Tilfældigvis møder jeg ham og hans kone på Storegade, jeg springer hen imod ham. Borgmesteren: Nå, det er måske indkvarteringen, De vil tale med mig om? Jeg: Så er det altså rigtig nok, at der er noget $\mathrm{i}$ gxre; hvorfor făr vi skoleledere ingen besked? Borgmesteren forklarede, at mens han i går var i Aabenraa, havde nogle tyske officerer henvendt sig til stadsbygmesteren og bedt om kvarter til større troppemængder (efter forholdene her). De ville komme igen onsdag for at træffe nærmere aftale. Jeg: Jamen, vi må da med det samme lægge en plan for at imødegå dette og redde; hvad reddes kan af skolerne. Jeg vil foreslà, at det i så fald bliver den ene skole, og at vi søger at samle de danske elever på den anden. Borgm.: Ja, det er også min tanke. - Jeg skyndte mig derpå til rektor, hvem jeg vækkede af middagssøvn. Han havde intet hørt; jeg forklarede ham, hvad der var på færde, og spurgte, hvad vi skulle gøre, hvis tyskerne simpelthen forlangte den ene af de danske skoler. Jeg: Kan De have os, eller skal vi prove at skaffe statsskolen plads på seminariet? Rektor: Vi kan i hvert fald ikke have Dem, det er der slet ikke plads til på statsskolen. Vi drøftede muligheden af spredt indkvartering på seminariet. Vi enedes derpå om, at såfremt indkvartering under ingen omstændigheder kunne undgås, ville det for det samlede danske skolevæsen være heldigst, om seminariet med sine talrige og rummelige lokaler blev bevaret. Så lovede 
Tonder Statsseminariums larere $i$ tovtrakining med statsskolens laerere $i$ september 1942.

Forstander M. Bredsdorff, bag hans skulder J. Utoft og $A$. Gravgaard, derefter tegnelarer Christiansen, overlarer Brahm, bagest (skaldet, med briller)

dr. phil. Niels Moller.

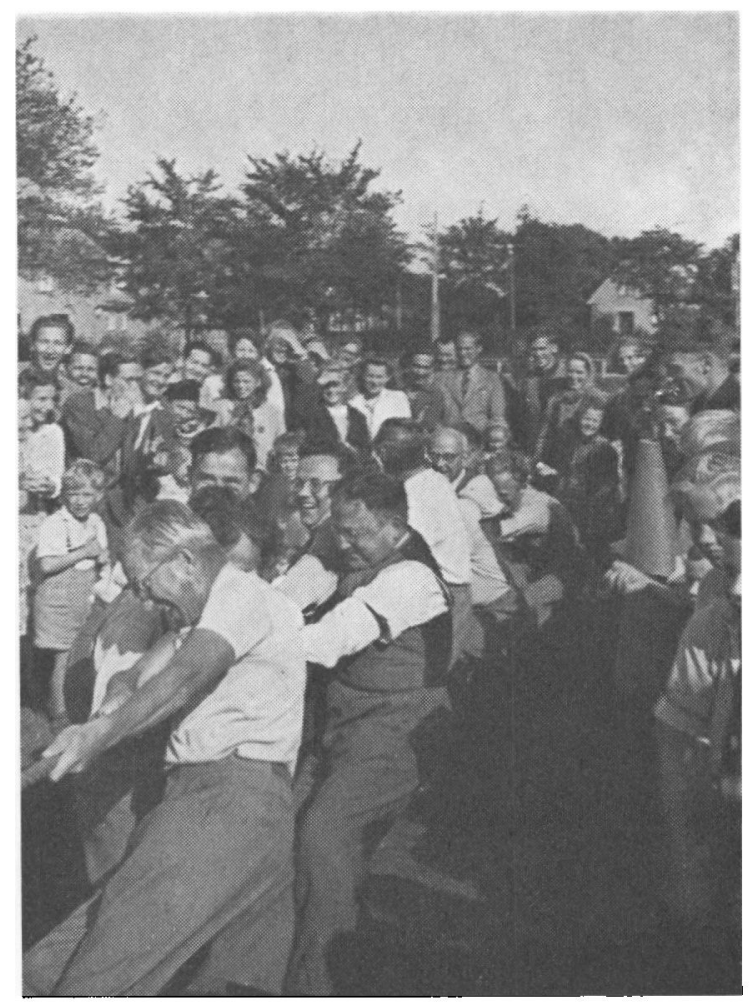

jeg til gengæld, at vi $\mathrm{i}$ enhver henseende skulle dele whalv skade* m. h. t. ulemper og indskrænkninger, samt, at jeg ville se at formå overlærer Brahm til at gå ind på delvis eftermiddagsskole for vore børn, så statsskolen kunne beholde skoletid om formiddagen, også af hensyn til de mange rejsende elever. (Det viste sig senere, at rektor havde misforstået dette punkt og mente, at statsskolen overhovedet ikke skulle renoncere på noget af undervisningstiden, men kun vi!).

Det lykkedes mig derefter at fả fat i stadsbygmesteren, der hxvdede, at han nok skulle værge vore skoler, men i nødsfald også fandt det rimeligst at overgive statsskolen og bevare seminariet. De tyske officerer skulle komme næste dag.

Om aftenen talte jeg med Brahm om tingene; han var meget forstående og var villig til at medvirke ved en sådan ordnings gennem- 
førelse, omend vi begge forudså betydelige vanskeligheder for alle skolerne; men der måtte *deles halv skade«.

Onsdag den 8. september. ( 6 års dagen for min tiltrædelse i Tønder). I det store frikvarter redegjorde jeg kortfattet overfor lærerne for de muligheder, der nu forestod.

Om eftermiddagen samtale med rektor Randrup. De tyske officerer var kommet kl. 13,30, havde besigtiget hele statsskolen og erklxret, at de kunne bruge den og den tyske borgerskole. På rektors henstilling, at man nøjedes med borgerskolen og Tonhalle o. l., svarede den ene officer, at her $i$ byen måtte der være "Parität « mellem de to nationaliteter; tog man en tysk skole, måtte man også tage en dansk; alt andet var "Quatsch! « De ville dog først komme om ca. 3 uger, til gengæld måtte der regnes med 1 a 2 år!!, bemærkede den ene officer. (Vi forbereder os nu på det værste).

$\mathrm{Vi}$ har $\mathrm{i}$ den første uge efter undtagelsestilstandens ikrafttræeden haft forskelligt besvær. Den 31. august kl. $10 \mathrm{kom}$ elev i 1. klasse, Hans Larsen, ind på kontoret og undskyldte, at han kom for sent; han var om aftenen få minutter over kl. 21 blevet taget ved sin bopxl af en tysk soldat og måtte så spadsere foran bajonetten ud til kasernen, hvor han tilbragte natten $\mathrm{i}$ et koldt værelse, siddende på en umagelig stol. Først kl. 9 næste morgen blev han løsladt. Ved siden af ham sad en 16 års dreng, hvem det var gået på lignende måde. Denne dreng havde jeg selv set aftenen før spadsere som fange foran bajonetten ud ad Østergade. Onsdag morgen den 1. september var det galt igen, 7 elever stillede på mit kontor lidt før $\mathrm{kl}$. 8. De var om aftenen ved 19-tiden blevet grebet af en tysk underofficer, mens de stod uden for pensionatet i Østergade og drøftede en praktikopgave til næste dag. Uden at tænke over det, stod de pludselig 7 mand sammen, og i det samme for soldaten ind på dem, greb en $\mathrm{i}$ brystet og skældte dem ud. Da en af eleverne, endnu inden han så soldaten, lod en replik (af deres samtale) falde til en kammerat, blev dette tolket som opsxtsighed, og 3 af dem måtte under stød af bøssekolber og spark $i$ haserne fortsætte halvvejs $i$ løb ud til kasernen. Her overfusedes de og truedes med indesparring, indtil de opgav navnene på de andre 4 kammerater, så lod man dem gå, med trussel om, at de skulle høre nærmere. De 4 skulle stille nu i tiden inden $\mathrm{kl}$. 10, og jeg sendte dem straks derud med den besked, at de 
endelig ikke måtte krybe eller undskylde sig; de skulle fastholde, at det var sket uden hensigt af nogen art, samt at de ikke havde villet krænke hverken personer eller regler. "Bare være stejle, og lad være med at komme med indrømmelser! « pålagde jeg dem.

Samme aften lå 7 bødebreve i min brevkasse; $50 \mathrm{kr}$. til hver af de 6, »weil Sie zu sieben in der Osterstrasse herumgestanden sind " dog $100 \mathrm{kr}$. til den syvende, fordi han - foruden det foregående »einem Unteroffizier gesagt hat, dass er weitergehen solle." En himmelråbende uretfærdighed, hvor enhver forklaring blev afvist, og klageren fik ret, blot fordi han klagede.

Torsdag den 9. september. De 7 elever stillede på mit kontor $\mathrm{kl}$. 7,50 og modtog deres bødeforlæg. De spurgte mig, hvad seminariet mente, og om en afsoning ville være seminariet imod. Aftenen i forvejen havde politimesteren imidlertid meddelt mig, at han desværre ikke ville få det mindste med sagen at gøre, og at eventuel afsoning ville ske i tysk fængsel. Dette meddelte jeg dem, og tilføjede, at jeg ikke ville forbyde afsoning, men nødig så den (det drejede sig om hhv. 5 og 10 dages fængsel), da rygterne så ville tage så stærk fart om seminariet; jeg sagde ikke, at et par af dem rimeligvis ville have svært ved at beherske sig under uvante forhold og derfor let kunne rage sig ind i værre ulykker. De var nu heller ikke særlig ivrige efter tysk straf, og da sagen blev kammerater og lærere bekendt, indkom der $\mathrm{i}$ løbet af to dage: Fra lærerværelset $185 \mathrm{kr}$. - fra eleverne i alle klasser 240,80 kr. - fra anonym velgører (borgmester Paulsen) $60 \mathrm{kr}$. - hvorefter de 7 »forbrydere " bad mig idømme dem en passende bøde. Jeg foreslog $15 \mathrm{kr}$. til hver, og med deisåledes indkomne $105 \mathrm{kr}$., nåede vi et beløb af 590,80 kr. Bøden blev erlagt rettidigt, "binnen drei Tage «, idet de 7 mand vandrede ud på kasernen i 2 grupper og fik deres kvittering. Restbeløbet indsattes på en særlig konto i Landmandsbanken. En anonym opringning til Det danske Kontor indeholdt et tilbud om pekuniær hjælp, så vi mødte adskillig hjælpsomhed $\mathrm{i}$ byen - og megen retfærdig harme, der $\mathrm{i}$ øvrigt til i går næredes stærkt ved synet af vore hjemmetyske medborgere $\mathrm{i}$ uniform og med et gult bind om armen som $»$ Heimwehr $*$ - Blindesamfundet* kalder folk dette kompagni, som vistnok har medvirket, sammen med de ustandselige angiverier, at slå en dybere kløft mellem dansk og tysk end nogen tidligere begivenhed her $\mathrm{i}$ Tønder. 
Det går $\mathrm{i}$ folkedybet, mærker man, når man taler med håndværkere og småfolk, og det vil blive siddende længe. I dag, torsdag, er Heimwehr forsvundet; det siges, at de efter eget ønske er fritaget forelobig; de skal have befundet sig meget ilde under deres danske medborgeres svidende øjekast - og mange af dem har nxppe ventet, at man ville gøre den brug af deres emsige øvelser på kasernen.

I går var det fru Eskildsens fødselsdag. Kl. 7,30 om morgenen blev hun ringet op fra Grand Hotel i Aabenraa; det var værten, der fortalte hende, at hendes mand, dr. Dahl og provst Schülein befandt sig dér på vej nordpå! De er altså ført bort fra Tønder skal formodentlig interneres. Så ser vi næppe Eskildsen $\mathrm{i}$ lange tider! $\mathrm{Vi}$ besøgte fru Eskildsen, der modtog mange blomster.

I aftes kom Frede Hansen ${ }^{33}$ med den overvældende nyhed om Italiens betingelsesløse kapitulation - det var altså ikke tomme ord fra Casablanca! Kort efter kom dr. Møller ${ }^{34}$ for at fortælle det samme, og mens vi lyttede til den nøgterne stemme fra Beromünster, ringede mag. Rahr: $:^{35}$ "Forstanderen har vel hørt...?* »Jeg er lutter øre ...!« »Så skal jeg ikke forstyrre ... Farvel! « «Farvel! « Den samtale kan fremmede øren vist næppe få glæde af.

Fredag den 10. september. Amtslægen, ${ }^{36}$ der kom fra Vojens, meddeler, at Eskildsen og de to andre vistnok er i Fredericia; man mener, at de skal $i$ en interneringslejr - Bygholm? Strib? Hindsgavl? Familien kan intet fă at vide. Om eftermiddagen lærermøde, hvor vi vedtog at anmode dr. Arndt fra statsskolen om at læse hr. Eskildsens tysktimer, mens jeg overtager hans timer i psykologi. Vi er enige om, at det varer længe, inden vi ser ham igen.

Lørdag den 11. september. Netop som jeg efter morgensang gav eleverne besked om hr. Eskildsens bortførelse og de usikre udsigter, kom frk. Enemark og meddelte, at Eskildsen vistnok blev løsladt i dag. Familien havde fået bud fra Fredericia. Almindelig vantro. Kort efter fik jeg ved samtale med fru Dahl bekræftelse. Alle de sønderjyske, civile fanger var uventet blevet losladt fredag aften, hun ventede sin mand med 14-toget! Hvorfor $\mathrm{i}$ alverden er de så blevet slabt til Fredericia?

Jeg gav klasserne besked om, at hr. Eskildsen alligevel kunne ventes til mandag, og bad dem samtidig undlade demonstrationer ved 
hans hjemkomst eller foran hans hus. Vi byder ham velkommen ved morgensangen på mandag.

Jeg gik selv ad vejen til Tønder $\varnothing$ st og traf Eskildsen i familiens arme. Han og jeg fulgtes til hans hjem, og han gav mig en kort beretning. Onsdag pludselig afsted i lastbil kl. 6,30 fra kasernen over Aabenraa, hvor de andre gidsler kom, og Haderslev til Fredericia. Meget dårlig behandling dér, anbragt i kasernens kælderrum, snavset og fuldt af fluer; først torsdag aften fik de bedre forhold efter vedholdende klager og protester. Men ingen breve og ingen besøg. Fredag aften kaldtes de op til kommandanten, der høfligt meddelte dem: På foranledning af partifører Jens Møller ${ }^{37}$ er De blevet frigivet og kan tage hjem. Derpå tilføjede han: Mine herrer, Tyskland har fjender til alle sider, stillingen er vanskelig, jeg beder Dem gå ud og bidrage til at skabe et bedre forhold mellem os. Vergessen Sie den ersten Tag, meine Herren! - Målløse forlod de danske arrestanter den store mands kontor. -

Søndag den 12. september. Dejligt søndagsvejr. Om eftermiddagen en kanotur til Korntved.

Mandag den 13. september. Ved morgensang sang vi: $\mathrm{Du}$ som våged over barnelivet, hvorefter jeg bød Claus Eskildsen hjertelig velkommen, eleverne hilste ham ved at rejse sig. Så sang vi med kraft: Det haver så nyligen regnet $-! \mathrm{Og}$ alle gik til arbejdet.

I det store frikvarter gav seminariet et glas vin til alle lærerne, og vi hilste på Eskildsen. Jeg foreslog ham at takke det tyske mindretals fører med Jeppes ord til dommeren: "Hvis I ikke selv havde hængt mig op, ville jeg have takket Jer, for I løsede mig neer igen!« - og forsikrede ham, at selv om han og jeg ikke altid havde været enige om, hvad der var klogt og rigtigt, så følte vi os ubetinget solidariske overfor slige fremgangsmåder som den, han her havde været udsat for. Jeg benyttede lejligheden til at takke lærerkollegiet for dets rolige og værdige holdning og gode arbejdsvilje under de sidste 14 dages krise.

Om eftermiddagen en fortrolig drøftelse af situationen med amtslæge Lausten-Thomsen, amtsskolekonsulent Svendsen og ingeniør Westh, i hovedsagen var vi enige, størst mulig tilbageholdenhed, passe det normale arbejde, lade alt andet, møder o. l. hvile, ikke foretage sig noget, der kræver tilladelse fra fremmed myndighed. 
Onsdag den 15. september. Om eftermiddagen drøftelse med rektor, overlærer og viceinspektør Brejlis om planen for alle tre skolers arbejde på seminariet, såfremt tyskerne tager statsskolen. Det bliver ikke let, men det kan gennemføres.

Fredag den 17. september. Om eftermiddagen en cykeltur til grænsen ved Sæd, hvor Friedy og jeg plukkede hyldebær af det sidste træ inden grænsen, og Friedy sad på grænsediget $\mathrm{i}$ septembersolen og malede en skitse af marsklandskabet.

Tirsdag den 21. september. I dag havde vi besøg af vor tidligere finske lotte, fru Anita Roos, ${ }^{39}$ fra Finland, der er kommet hertil for at hente 12 finske børn, som skal hjemsendes i morgen her fra Tønder amt. Hun har arbejdet på landet i sommer og har det derfor temmelig godt; ernæringsforholdene bedre end i fjor, især var høsten $i$ år ret god. Hendes meget forsigtigt udtrykte opfattelse er den: Danmark er lykkeligt, for så vidt som dets stilling er klar; det har et stort ønske, går det $\mathrm{i}$ opfyldelse, er Danmarks fremtid nogenlunde sikret. Finland ved, at enten krigen făr den ene eller den anden udgang, er dets skxbne tragisk og dets fremtid usikker, for ikke at sige håbløs. Finland ville gerne have fred, såfremt det blot $\mathrm{i}$ mindste måde kunne stole på Rusland; men det er umuligt. Om eftermiddagen holdt lokalkomitéen en slags afslutningsmøde med festligt kaffebord for fru Roos på »Tønderhus«. Efter beretninger og regnskab talte fru Roos lidt om sit ulykkelige fædreland og bragte en tak for, hvad Danmark gør for børnene. Om aftenen spiste vi hos ingeniør Westh. Her talte jeg kort om Finlandshjælpens linje; vort arbejde begyndte i 1939 under Vinterkrigen som et rent humanitært hjælpearbejde for børnenes og vel også for Nordens skyld. Der var folk, som dengang bebrejdede os, at vi ikke ville sende våben og ammunition eller deltog $\mathrm{i}$ agitationen for at få frivillige afsted. $\mathrm{Da}$ den næste krig brød løs, stod mange usikre; vi fastholdt vor linje: at hjælpe Finlands børn, og nu fik vi bebrejdelser - undertiden fra samme hold som før - fordi vi overhovedet ville gøre noget for Finland. Det må vist vare bevis for, at vi har søgt at gøre det, der var rigtigst $\mathrm{i}$ de vanskelige situationer.

Onsdag den 22. september: I dag kl. 11,49 afrejste de 12 finske børn under ledelse af fru Roos. Bevæget afsked med de sørgende 
plejeforældre på banegården; det var gribende og rørende at se den kærlighed, der forbinder disse fremmede børn og de jævne, vestslesvigske bønder.

Nu synes det uundgåeligt, at statsskolen skal benyttes til tysk indkvartering om 14 dage. Nyt tysk officersbesøg i går!

Lørdag den 25. september. Ved morgensangen fejrede seminariet kongen med en kort tale (se lejlighedstaler). I øvrigt regelmæssig undervisning.

Søndag den 26. september. Kongens fødselsdag. Almindelig og kraftig flagning over hele byen samt smuk vinduespynt $i$ alle danske forretninger. Vi gik til gudstjenesten kl. 10, kirken var fyldt. Efter en kort og god prædiken talte pastor Magle smukt og varmt om $»$ Kongen af Guds nåde, det sidste vi har tilbage af det engang frie Danmark! « Stående sang menigheden "Kongernes Konge « og det $i$ sig selv ikke meget værdifulde digt tolkede her sønderjydernes hjertegrebne følelser, mange havde tårer $\mathrm{i}$ øjnene. På hjemvejen mødte jeg Eskildsen, der fortalte, at begge jernbanelinjer fra Tønder var blevet sprængt talrige steder $\mathrm{i}$ nattens løb, og at der vist var almindelig jernbanesabotage over hele landet. Foruroligende rygter om snarlig oprettelse af et protektorat, Terboven, Daluege, Best??? - Nå ja, lad os nu se, der har været så mange rygter.

$\mathrm{Da}$ vi nu kl. 17,30 kom hjem fra en smuk tur gennem byen og til "Tønderhus" med den ny kongebuste, rullede politiets radiobil gennem gaderne: Restaurationslukning fra kl. 19, spærretid fra 20-6, alle veje fra og til Tønder om natten spærret af tysk militær. Ja, det var jo, hvad man nu måtte vente.

Torsdag den 30. september. Rygterne svirrer fremdeles; men det er umuligt at få nogen sikre holdepunkter. Nu ringede seminarieforstander Haar, Ribe, for lidt siden (kl. 21) og meddelte mig, selv noget foruroliget, at han fra rigsdagsmænd, der var hjemvendt fra København, med sikkerhed vidste, at $i$ lobet af natten ville en protektor blive udnævnt, måske v. Neurath. „Og hvad så -«, spurgte Haar, »så får vi sikkert loyalitetserklæringer forelagt, så må vi jo prøve at handle ens «. Jeg fandt emnet lidet egnet til telefonsamtale og mente, at foreløbig måtte vi afvente departementschefernes holdning. Ja, men mon vi overhovedet făr at vide, hvad de svarer eller 
gør, spurgte Haar. Nej, det er meget muligt, men alligevel kan man vanskeligt tage stilling til en situation, der ikke foreligger endnu. $\mathrm{Og}$ i mandags vidste Eskildsen sikker besked, og der skete dog intet, så vidt vi ved. - Det er underligt at gå $i$ seng $i$ denne tid; man vågner ikke sjældent ved 3-4-tiden i nattemørket og tænker på, at det vist er i dette sjaleligt og legemligt matte og ængstende øjeblik, at der sker så meget rundt om, som ingen får at vide.

Lørdag den 2. oktober. ${ }^{40}$ Så kom det. Og igen på en anden måde end ventet. Den officielle radiomeddelelse om "hjemsendelsen ", der indledes med den knudrede ablativsæetning om jøderne, der er wudskilt af det offentlige liv «, er på sin vis et endnu mere knugende og frygteligt slag end 9. april og 29. august. Hvorfor dog dette meningsløse? Var ikke jødespørgsmålet nu skudt noget i baggrunden? Er det en prestigeløsning af den politiske hårdknude, for der består jo ingen som helst sammenhæng mellem "hjemsendelsen " og pogromen, ejheller har vi tidligere fået at vide, at det var jøderne, som drev sabotage (man kunne dog $\mathrm{i}$ det mindste have propaganderet lidt $\mathrm{i}$ den retning!)

Kl. 16,30 fortrolig samtale med amtslægen, Nic. Svendsen og amtslandinspektør Mosbech på dennes kontor. Vi er alle svært tyngede og rystede over denne nye udvikling. De sikre efterretninger er få. Men vi er enige om, at der ikke er andet at gøre end at blive på sin plads og gøre sit arbejde, skønt det til tider kan synes så ligegyldigt. Tilfældigt kommer det frem, at vi alle har gjort den samme erfaring, man er dødtræt om aftenen $i$ disse perioder og kan egentlig ikke udrette mere end det strengt nødvendige. „Godt, at vi er færdig med Tonder-bogen «, siger Mosbech, og jeg giver ham ret.

Jeg går hjem og læeser Grundevigs ord om jøderne i Danmark (Mands Minde, 21. november 1838) og Henry Georges store lovtale over Moses.

Tirsdag den 5. oktober. En bevæget eftermiddag og aften. Kl. 13 møde med borgmesteren, rektor, overlærer samt forældrenævnsmedlemmer om skoleordning under eventuel indkvartering. Besigtigelse af "Tønderhus og ungdomshjem. Kl. 14,30-15 affattelse af en skrivelse på de danske skolers vegne om hjxlp til at få "Tønderhus «" lokaler til hjælp ved undervisningens gennemførelse. Kl. $15 \mathrm{med}$ 
amtmanden og pastor Magle i bil til seminariets gård „Gørresmark «, det årlige syn. Kaffe sammen med forpagter Linnet. Amtmanden ret tavs, mener, at undtagelsestilstanden kan vare længe endnu, folk og konge har jo taget en så fast holdning, at der ikke er nogen mulighed for en losning, lad det bare gå videre.

$\mathrm{Da}$ jeg kommer hjem ca. kl. 17, ringer amtsskolekonsulenten: "Undtagelsestilstanden vil blive ophævet i morgen! «Hvad så?* "Ingen ved det —«. Kl. 17,15 opringning fra Jelling seminarium, forstander Futtrup spørger om vor stilling i Tønder? Arbejdes der? $\mathrm{Da}$ jeg er uforstående, oplyser han, at der er en slags skolestrejke på de tre københavnske privatseminarier, og at han har talt med forstander Ernst Larsen, der misbilliger denne noget planløse efterligning af universitetets beslutning om lukning af sympati med jøderne. Vi bør vel afvise det, mener Futtrup. Det er også min mening.

Kl. 19 ringer amtslægen og beder om en samtale privat. Lidt efter kommer han. Han har haft besøg af Jakob Petersen, ${ }^{41}$ Aabenraa, der på foranledning af en henvendelse fra Askov har droftet spørgsmålet om demonstrative sympatitilkendegivelser for jøderne med mænd som Hans Schmidt, ${ }^{42}$ Kollund, Hans Andersen, Kongsbjerg, Johs. Juhl, ${ }^{43}$ Branderup, og Nic. Svendsen. De er enige om at fraråde demonstrationer, der er slag i luften og »unyttige og farlige «, og Jakob Petersen har bedt ham meddele mig dette synspunkt, hvis der kommer uro $\mathrm{i}$ Tønder. Det er en støtte at kende det sønderjyske standpunkt, der gerne er fornuftigt og velovervejet $\mathrm{i}$ disse tider. Kort efter kommer Th. Lauridsen, elevforeningens formand, og Ole Juhl-Pedersen, de viser mig en hektograferet skrivelse, hvoraf det fremgår, at "representanter for københavnske seminarier har besluttet at demonstrere ved at udeblive fra undervisningen $i$ denne uge, « kammerater ved andre seminarier opfordres til at slutte sig til omgående. Jeg takker de to loyale elever, fordi de forelægger mig spørgsmålet, og gør dem opmærksom på skrivelsens totale anonymitet; hvem har sendt den - det kan være et helt andet bureau. Det har de selv tænkt på, og de er meget betænkelige, men vil gerne forelægge sagen og er klare over, at dette vil vække stor uro. Jeg meddeler dem, at jeg bestemt må fraråde at deltage $i$ en sådan hovedløs demonstration, såfremt den ikke bliver fast organiseret og kollektiv, og indrømmer, at vi vanskeligt kan forhindre dem $i$ at forlade seminariet. $\mathrm{Vi}$ enes om at sove på dette. 
Onsdag den 6. oktober. Det begyndte straks om morgenen. Fra Haderslev og Ribe meddeler forstanderne, at der er uro og strejketrusler, der afholdes møder, undervisningen er delvis suspenderet. Jeg meddeler min stilling og de sønderjyske udtalelser, og de to andre forstandere beslutter at stille sig på samme standpunkt. Lærerrådet sammenkaldes til et kort møde kl. 8,45. Man enes om: 1) at fraråde aktionen for Tønders vedkommende. 2) at prøve at erfare Dansk Seminarieforenings standpunkt. 3) at erklære sig villig til at deltage $i$ et fallesmøde med eleverne.

K1. 11 sammenkalder jeg hele seminariet i festsalen. Efter et par indledende ord om de usædvanlige begivenheder og en henstilling om ikke at lade sig rive med til ubesindige og tankeløse demonstrationer, taler elevforeningens formand. Med hævet stemme redegør han for de modtagne oplysninger fra andre seminarier og opfordrer til udeblivelse fra arbejdet $\$$ som de andre kammerater gør «. Der følger en pause, så taler Peter Nissen Hansen, S IV. „Vi bør tænke os om, før vi handler. Hvad gavner vi jøderne, hvad skader vi os selv? Kan vi ikke finde bedre måder at hjælpe jøderne på." Pause. Så taler Svend Gammelgaard, S I: "Efter 9. april forholdt vi os rolige og fandt vor egen kampmåde; efter 29. august gjorde vi det samme. Mon vi ikke skal følge den retning, jeg anbefaler, at vi passer vort arbejde «! Pause. Der er tydelig nok uro i salen, men ingen ønsker at sige mere. Så taler formanden igen, han føler sig svigtet, "flertallet« er imod ham, mener, skønt jeg på forhånd har afvist afstemning, han vil bøje sig loyalt. Så er timen endt, og jeg beder enhver gå til sit. Det var første puniske krig, men uroen har ikke lagt sig helt.

I pausen kl. 13 er de alle på eget initiativ påny gået op i festsalen, og her har vist den stumme opposition i høj grad fàet mæle! $\mathrm{Da}$ der skal være korsang for børnene, må hele forsamlingen fortrække, men går ikke til time; man samles i læsesalen, og lærerne får kun ganske få elever den første halve time. Jeg afventer begivenhederne på kontoret. Kl. ca. 13,30 vender eleverne tilbage til undervisningen, i stærk diskussion. To selvbestaltede ledere kommer ind og aflægger rapport, det viser sig, at formanden er blevet fornærmet og ikke har deltaget $\mathrm{i}$ dette ureglementerede møde, som heller ikke er sammenkaldt af ham. Det synes at fremgå, at det er vedtaget at afvente en kollektiv optræden fra landsrådets side, $3 / 4$ af eleverne har stemt for 
at passe arbejdet og afvente, om der bliver almindelig stemning, men der er intet protokollat, og det diskuteres senere, hvad man i grunden enedes om ved dette private møde.

I øvrigt undskylder de to udeblivelsen fra timen, og resten af eftermiddagen går normalt. Men der er tydelig nok uro over hele landet, telefonen kimer, og i eftermiddagens løb taler jeg med Ribe, Haderslev, Jelling, Ranum og Silkeborg, overalt lærer- og elevmøder; gennemgående modstand fra ledelsen, dog kapitulerer Ranum om eftermiddagen. Ribe giver ordre til, at undervisningen skal begynde kl. 12, men kun lxrerne møder. Og eleverne bearbejder hinanden fra seminarium til seminarium. Det er en typisk psykose, med voldsomme suggestive midler: "Nu er der 7 , nu er der 9 seminarier, nu mangler vi kun jer 0 . s. v.« Om aftenen lærerrådsmøde $\mathrm{i}$ min stue, enighed om, at grundlaget er for skrøbeligt og aktionen for planløs, vi må ikke give efter, skønt det ser ud til, at vi efterhånden isoleres. Telefonisk foreslår Jelling, at vi betragter affæren som wintern «! En kollektiv skolestrejke som en intern affære!! Skal vi så ikke hellere foreslå eleverne at $\mathrm{p} . . . \mathrm{i}$ bukserne! Det store spørgsmål: Bliver trykket så stærkt og agitationen så pågående, at de overhovedet ikke kommer i morgen. Med det spørgsmål skilles vi kl. 22.

Torsdag den 7. oktober. En skæbnesvanger dag. De var der alle kl. $8 \mathrm{i}$ morges, men der var adskillig uro at spore, især i de ældre klasser, hvor vi har for mange brushoveder for tiden. Jeg har pædagogik med S. I. i første time, og vi interesserer os meget for Sokrates. Stor agitation i frikvarteret, og S. III er ret uopmærksom overfor Rosseau i næste time, en afstemning synes $i$ gang.

I 2. frikvarter kommer formanden og melder mig ophidset, at nu er det umuligt at komme videre, eleverne er begyndt at gå, vi kan lige så godt standse straks. Han kan ikke oplyse noget om resultatet af afstemningen (det viser sig senere, at der ingen optælling skete), men ved en slags kup har de $x$ ldre klasser overmandet de yngre, og nu vil man gå sin vej. "Holdt «, råber jeg, »sådan render vi ikke fra hinanden, lad os så skilles på anstændig vis oppe i festsalen, det andet kan vi ikke være bekendt! "Stafetter løber ud og standser de bortdragende, og få minutter efter er alle forsamlede $\mathrm{i}$ festsalen. Vi holder et kort lærermøde. Vi er enige $i$ at fastholde vort standpunkt, kun Eskildsen vakler, følsom overfor stemninger og uhyre ømfindt- 
lig overfor flertal, som han er, han vil, at vi skal "anerkende" elevernes standpunkt og bøje os. Det er hele aktionens pinligste øjeblik, men de øvrige kollegers støtte redder situationen, vi kan ikke anerkende dette, sådan som det har udviklet sig; vi er derimod nødt til at tage det til efterretning. Så går vi samlet op $\mathrm{i}$ festsalen, eleverne rejser sig, formanden leder mødet, eleverne har besluttet at udeblive, fordi flertallet af seminarier gør det, og meddeler os dette på sømmelig vis. Jeg taler kort og indtrængende, vi beklager denne handling, som vi ikke kan anerkende og ikke finder fornuftig, men vi tager beslutningen til efterretning og vil så prøve at mødes uden bitterhed næste mandag. Jeg advarer mod den nationale heroisme, der nu kan ligge længe $\mathrm{i}$ sengen, og foreslår, at man så virkelig gør noget for jøderne, arbejde på landet, og at det hele ikke bør være ferie. »Og så går forstander og lærerråd!« Eleverne bliver. På trappen roser Eskildsen mig stærkt, det kunne ikke være gjort bedre.

Selv er jeg ikke glad. Og det er vist de fleste af eleverne heller ikke, derom kommer der snart vidnesbyrd, en usikker og vaklende formand søger trøst hos mig allerede kl. 13, og der kommer flere, der fortryder eller vakler. K1. 13,30 kommer Bille og meddeler mig, at han fra den tyske lærer G. ${ }^{44}$ har modtaget et indtrængende advarende ord: Se at få Deres kammerater til at møde igen snarest, ellers er det ikke sikkert, De får lov at være herrer på seminariet ret længe!! Det er, hvad jeg har frygtet dybest nede; der er ingen lejlighed til at kontrollere rigtigheden af denne advarsel, men jeg kender lærer G. og ved, at han mener os det godt. Jeg må tænke på den tyske lærer E., ${ }^{45}$ der under forrige krig lejlighedsvis lod det danske mindretal tilflyde en nyttig oplysning. Og for mig er der nu ingen tvivl, nu skal der handles, og det straks! Eleverne vakler og er suggeret ud i en halvbevidst, ansvarsløs tilstand - og jeg mindes ikke siden elevstrejker på Roskilde Højskole 1927-30 at have oplevet en lignende voldsom stemningsbølge. Jeg beder elevhjemmets piger og andre elever, der fxrdes ved seminariet, om straks at sammenkalde alle elever til kl. 15, en yderst vigtig meddelelse fra forstanderen! Og de iler afsted. Så sammenkalder jeg lærerrådet, Eskildsen er igen tøvende og usikker, hvad betyder denne meddelelse; jeg erindrer diskret om, hvad jeg ved fra den forrige krig, og han bliver tavs. De øvrige lærere indser snart, at her leges med en farlig ild, angivere kan snart samle uviljen mod os og gå til kommandanten! 
og hvad så, er det hele en pinlig indkvartering værd, med alle dens ubehagelige og farlige følger? Bestemt ikke! Utoft ${ }^{46}$ fremsætter det rette forslag: $\mathrm{Nu}$ ingen diskussion, en kort redegørelse og så skolens ultima ratio, en befaling. Og dette enes vi om. Det er nu både nødvendigt og det eneste rette. Kl. 15 er alle samlede $i$ festsalen, en spændt og urolig forsamling. Kun forstanderen taler: Vi har hele tiden været bekymrede, vi har fået gode grunde derfor, en meddelelse, som kan koste en mand stilling og liv, erindrer os om vor udsatte stilling, på endnu mere indtrængende vis end sønderjydernes henvendelse. Derfor en befaling: Alle moder fredag morgen kl. 8, det kan gælde seminariets velfærd. Udeblivelse vil blive betragtet som en disciplinær forseelse med alvorlige følger for den enkelte! Så går lærerrådet og jeg.

Der var vistnok meget bitter stemning, for det tjener elevërne til xre, at de om formiddagen havde vedtaget at anmelde afrejse fra byen, at søge arbejde hos landmænd til fordel for jøderne o. 1. (naturligvis kun enkelte). Men jeg tvivler ikke om, at de vil komme. For mig er denne anvendelse af metoder, som vi hader og bekxmper, heller ikke behagelig, og det er en tung eftermiddag. Vi besøger frk. Enemark, træffer der Hans Andersen, Kongsbjerg, der fuldt ud billiger, hvad jeg har gjort, det eneste rette, han har selv afvist tilbud om hjælpere fra seminariet under disse forhold. Om aftenen ringer politimesteren for at høre, hvad der er sket. Han er glad, at der igen hersker ro, øjeblikket er ikke til at spænde buen for højt hernede. Rektor er også beroliget, der havde været nogen lyst til efterligning på statsskolen, nu falder der sikkert ro også dér.

\section{II}

\section{Forår 1945.}

Tirsdag den 27. februar meddelte borgmesteren mig, at han havde fået skriftlig Vorbescheid, gældende bl. a. seminariets bygninger. Man mente dog, det ville vare lidt endnu, inden der kom mere. Da bygningerne allerede onsdag den 21. februar var blevet opmålt af et par Gefreitere fra statsskolen, følte vi os ingenlunde sikre. Rektor, overlæreren og jeg besluttede at træffe nødvendige forberedelser til flytning og $\mathrm{i}$ øvrigt ikke på nogen måde lade os anfægte. Undervisningen skulle fortsættes til det sidste. 
Fredag den 2. og lørdag den 3. marts var her instruktionskursus for Tønderegnens lærerkredse. Trods en ren orkan om fredagen var besøget meget stort. Glenstrup ${ }^{47}$ talte om geografiundervisningen, Brejl holdt demonstration. Jeg begyndte anden dags møde med det udtryk, vi daglig anvendte: "Vi er her endnu «. En henvendelse til statsskolekonsulenten om at få gymnastikeksamen fremrykket, af hensyn til de sig nærmende og $\mathrm{i}$ omegnen $\mathrm{i}$ rask tempo stedfindende beslaglæggelser, blev imødekommet. Gymnastikeksamen skal finde sted 9. og 10. marts. Gid det må lykkes!

Søndag den 4. marts. Seminariets forårsmusikfest kl. $16 \mathrm{i}$ *Tønderhus «, der er beslaglagt. Mange mennesker, smuk fest. Seminarieelev H. P. Høgh i IV klasse talte og kom overraskende ind på en lidt lang omtale af seminariets ledelse $\mathrm{i}$ disse år, som eleverne tilfulde forstod og sluttede sig til, de tilbageviste beskyldninger for at have bagtalt deres skole. Talen var umådelig velment og pæn, blev desværre af enkelte hysteriske personer tolket som et angreb på aktivismen - hvad den aldeles ikke var - Jeg kunne meddele, at Schackenborg nu var ved at blive belagt, og at der næppe var længe igen. Med en omtale af fraværende kammerater og landsmænd $i$ fangenskab sluttede den kønne fest.

Mandag den 5. marts. Ca. kl. 16 meddelte vor pige mig, at der stod en samling tyske soldater $\mathrm{i}$ seminariets gård. Jeg gik ud til dem og spurgte, hvad anledningen var. En Kapitän svarede, at man foreløbig ønskede selv at orientere sig og ikke ønskede at tale med mig. Jeg sagde, at sagen var vigtig for os, og at jeg derfor ville sætte pris på at få oplysninger om, hvad man havde i sinde. Man meddelte så, at man agtede her at indrette en stor militær skole. Hvor hurtigt vi kunne rømme? Jeg krævede mindst tre døgn. Det skal De få, i morgen făr De besked "Ob und wann wir kommen!« De er formodentlig ude på egen hånd.

Tirsdag den 6. marts. Kl. 15 ser jeg en større stab begive sig ind $\mathbf{i}$ hovedbygningen. Da jeg spørger dem, hvad meningen er med uanmeldt at trænge ind $\mathrm{i}$ seminariet, oplyser en lille bidsk herre med griseøjne og mensurar på hage og kind, at han er en major med stab, der skal indrette en $»$ Fahnenjunkerschule og det meget hurtigt. Han 
forlanger at se det hele, og da jeg protesterer mod at vise ham det privat beboede elevhjem - en protest, der hidtil altid blev taget til følge - afviser han dette og vader forud, ledsaget af en lille uniformeret huntysker, som børnene senere kalder $\gg$ Adolfine*.

Elevhjemmet beses, og det erklæres, at her skal bo $60 \mathrm{kvindelige}$ officerer el. lign. Derpå forlanger han adgang til *Helligåndshuset. $\star^{48}$ Heftig protest fra min side, huset har private tjenesteboliger forneden, oven på er der bibliotek, det må ikke medregnes i beslaglæggelsen. Den lille iltre major ruller martialsk med øjnene, han trænger åbenbart til bedrifter, brutalt går han forbi mig, op i biblioteket og klasseværelset og erklærer, at det hele skal tages $\mathrm{i}$ brug.

$\mathrm{Nu}$ protesterer jeg kraftigt mod hele denne behandling og forlanger en klar skriftlig ordre, før vi agter at foretage os noget som helst, jeg henter afskrift af Vorbescheid af 26. februar, han læeser den igennem, synes et øjeblik at blive usikker. "Er det denne sag «, spørger jeg. "Es könnte dasselbe sein! « - Konjunktiven forekommer mig interessant.

Han lover mig sluttelig besked og ordre inden aften og forføjer sig væk. Tilskyndet af ing. Westh og pastor N. P. Nielsen, Højer, ${ }^{49}$ der er kommet til, beslutter jeg en lynopringning til Silkeborg og den tyske kommandant i Haderslev. Silkeborg kommer først, og fuldmægtig Henningsen oplyser, at der er løbende forhandlinger om seminariet, endnu kl. 13 var der ikke truffet afgørelse, han vil ringe mig op senere $i$ aften. Kommandanturen i Haderslev giver, efter at man som sædvanlig har måttet gennem tre-fire instanser, der intet ved, at det vistnok er rigtigt med denne skole. "Er der ikke tale om et lazaret? " Måske, det ved man ikke rigtig, man foreslår henvendelse til den lokale kommandant $i$ Tønder! (Den samme, som om formiddagen havde meddelt borgmesteren, at han intet kendte til disse sager). Vi kommer helt $\mathrm{i}$ humør over disse vidnesbyrd om organisation og målbevidsthed, men enes dog om at rømme gl. øvelsesskole for inventar. Det kan flyttes over i bryggeriet overfor, hvorfra vi siden kan flytte det til lokaler i byen. Ved sin afgang har majoren mumlet noget om, at der måske allerede kom soldater i nattens løb. Så smider vi dem derind. Eleverne foretager flytningen, efter at de har fået at vide, at det meste af det, de nu har set, bør opfattes som nervekrig!

Telefonisk forespørger hr. Gravgaard mig om flagstængerne, og 
inden aften er det sivet ud til eleverne, at seminariet indtil videre ikke får brug for sine flagstænger. De er da også væk næste morgen. De skal males nu til foråret!

Så skete det onsdag den 7. marts. Sent tirsdag aften opringning fra Silkeborg. Beslaglæggelsen er sket, hele seminariet, formålet ubekendt. Silkeborg kunne ikke udrette mere for os. Man henstillede, at forstanderen selv forte forhandlingerne videre for at redde, hvad reddes kunne.

Onsdag den 7. marts. Første time med S. III, Grundtvig. Jeg afbrød den $\mathrm{kl}$. 8,30, da jeg ventede allehånde og sammenkaldte ved opslag hele seminariet $\mathrm{i}$ festsalen kl. 8,55. Kl. 8,40 kommer Oberleutnant for Junkerstab og forlanger øjeblikkelig rømning, jeg kræver skriftlig ordre, den loves igen. Han sendes bort for at bese det hele med pedellen. I festsalen redegørelse for stillingen, opfordring til sammenhold fremdeles, også under de kommende kår. Opfordrer eleverne til en værdig holdning og til selv at tage stilling, ved klassemøder drøfte stillingen, vælge 2 tillidsmænd i hver klasse og derigennem give udtryk for deres holdning.

Vi synger Alt står i Guds Faderhånd, som 9. april. Seminarieeleverne holder klassemøder, statsskolen holder morgensang, og dens elever begynder derpå temmelig forvirret at flytte inventaret bort. Rektor, overlærer og jeg drofter lokaler $i$ byen med ing. Westh. Stor uro på alle gange, hvor tyskerne vandrer rundt og skriver med kridt på dørene. Rektor må ud og søge at skaffe ro. En pinlig episode - en sentens på en tavle - ophidser tyskerne voldsomt og bilægges kun med en dyb undskyldning fra rektor og løfte om straf. - Endelig får vi statsskolens elever sendt hjem. Lærerråd $\mathrm{kl} .11 \mathrm{og}$ igen kl. 14 med tillidsmandsråd, der udtrykker fuld enighed. Kl. 15 begynder vi at flytte. Torsdag den 8 . marts flytning til byen. Torv i mængde. Elevhjemmets pensionat til præstegården. Fredag kl. 8 alt $\mathrm{i}$ orden.

12. marts 1945 .

Til undervisningsministeriet, 1 . dept. 2. kt.

I fortsættelse af indberetning af 4 . d. m. om en gennem borgmesteren modtaget $»$ Vorbescheid « om beslaglæggelse af Tønder Statsseminarium skal man herved tillade sig at indberette følgende: 
Mandag den 5. marts kl. 16 indfandt sig i seminariets gård en samling tyske officerer, der tillod sig at vandre frit rundt i lokalerne. På forstanderens forespørgsel erklærede de, at her skulle indrettes en militær skole. Herom ville seminariet modtage nærmere besked, og der lovedes en frist af mindst 3 dage. Man gjorde derfor klar til hurtig udrykning, men fortsatte undervisningen uden at lade sig forstyrre.

Tirsdag den 6. marts kl. 15 indfandt sig en major med stab. Han forlangte, at alt skulle tømmes omgående, der skulle indrettes en »Fahnenjunkerschule« på 500 mand. Trods forstanderens energiske protest forlangte han også læsesal, håndbibliotek og praktikklasseværelse i Helligåndshuset rømmet, skønt der i stueetagen er tjenesteboliger for overlærer og pedel. Endelig beordredes, ligeledes mod protest, elevhjemmet rømmet; det skulle anvendes til kvarter for 60 kvindelige soldater. Jeg krævede en særskilt skriftlig beslaglæggelsesordre samt meddelelse fra stiftamtmanden i Silkeborg, før vi foretog os noget. Man lovede en skriftlig ordre, men den kom ikke. Jeg henvendte mig derpå direkte til Silkeborg, der oplyste, at beslaglæggelsen af seminariet endnu ikke var endelig afgjort, men antagelig ville følge, samt til den tyske kommandant i Haderslev, der havde underskrevet "Vorbescheid " af 26. februar, med forespørgsel, om dette var samme sag. Et uklart svar lod os forstå, at der forelå flere muligheder. Samme aften kom der telefonisk besked fra Silkeborg, at beslaglæggelsen af seminariet nu var sket, man henstillede til forstanderen selv at forhandle med de tyske myndigheder om ordningen.

Onsdag morgen kl. 8,30 ankom en Oberleutnant med mandskab og krævede hurtig rømning. Mens han besigtigede lokaler og beslaglagde inventar, samledes samtlige seminarielærere og -elever $i$ festsalen. Her gav forstanderen en kort redegørelse for det skete, gav en oversigt over de muligheder for fortsættelse af nødtørftig undervisning, som forelå, bad eleverne selv afgøre, om de ønskede at fortsætte på disse vilkår, eller om undervisningen hellere burde stilles $\mathrm{i}$ bero, samt om de ønskede andre retningslinjer for deres færd udadtil end dem, der hidtil gjaldt. Seminarieeleverne holdt derpå klassemøder og gav derpå gennem tillidsmænd udtryk for fuld tilslutning til at fortsætte arbejdet såvidt muligt på samme måde og under samme krav som hidtil. Derpå tog man fat på flytningen. Denne 
tilendebragtes $\mathrm{i}$ løbet af onsdag eftermiddag og torsdag, således at hele seminariet kunne samles til fælles morgensang i Missionshotellets sal fredag den 9. marts kl. 8 og derfra begive sig til de nye lokaler. Samtidig var indkvarteringen af de 20 unge piger fra elevhjemmet gennemført ved stor hjælpsomhed fra byens danske borgerskab, og elevhjemmets pensionat genoprettet $\mathrm{i}$ den danske prastegårds storstue under inspektrice frk. Jakobsens ledelse.

Klassernes fordeling er nu følgende: I seminarieklasse, en tegnestue i Statens Jordlovsudvalg, Allégade 4, II, III og IV klasse, 2 tegnestuer og et stort kontor i Hedeselskabets bygning, Ribelandevej, præparandklasser i DUI's foreningslokale $\gg$ Falkereden , Dragonvej, håndgerningslokale, sygehusets funktionærbolig, seminariets kontor og arkiv $\mathrm{m}$. v., forstanderboligen. Om børneskolens ordning følger indberetning fra overlæreren. Man har lagt vægt på såvidt muligt at opretholde en begrænset undervisning for alle klasser, og dette er indtil videre lykkedes.

Det ikke beslaglagte inventar er dels anvendt i de nævnte lokaler, dels stuvet sammen på lofterne, ligesom håndbiblioteket er magasineret.

$\mathrm{Da}$ det for benyttelsen af flere af de nævnte lokaler, som også for nogle af dem, der benyttedes af øvelsesskolen, var en udtrykkelig betingelse, at der måtte stilles brændsel til rådighed, da opvarmning ellers var udelukket, har man fordelt visse kvanta af seminariets forråd af torv til disse nye lokaler, idet der fra tysk side ikke stilledes $\mathrm{krav}$ om nogen som helst opvarmning af de beslaglagte bygninger.

Man har under denne force majeure tilladt sig at handle pr. konduite og med skolernes vel for øje. Om de regnskabsmæssige spørgsmål, som lejen af lokaler i præstegården til elevhjemmet, af DUI's bygning samt de af øvelsesskolen benyttede lokaler, den af statsskolen hidtil lejede restaurant $*$ Schweizerhalle«, byens to danske børnehaver samt et lokale i luftværnskontoret, rejser, vil indberetning følge, når man har oversigt derover. Det er foreløbig lykkedes at holde sammen på skolernes undervisning og på elevhjemmet, hvilket sidste var yderst påkrævet, da byens øvrige pensionater er ude af stand til at tage flere gxster.

Ved beslaglxggelsen stillede forstanderen udtrykkeligt krav om ret til benyttelse af den ny gymnastiksal til den af statskonsulenten 
fastsatte eksamen i faget gymnastik fredag den 9. og lørdag den 10. d. m. Dette krav er blevet respekteret, således at eksamen gennemføres på normal vis med idrætsinspektør Braae-Hansen som censor. Først en time efter, at den var tilendebragt, begyndte tyskerne at slæbe halm m. v. ind i salen. Alle lokaler er nu fyldt med halm og andre arrangementer.

Mandag den 12. d. m. kl. 9,30 aflagde Oberleutnant mig visit. Han gjorde en dyb undskyldning for den ulejlighed, der var voldt. Det hele var nu aflyst, og hans stab skulle rejse kl. 12. Lokalerne var fremdeles beslaglagt, men vi kunne forføje frit over inventar $\mathrm{m}$. v. Sandsynligvis ville seminariet senere blive taget $i$ brug til lazaret. Seminariet står $\mathrm{i}$ dag aldeles tomt, og der er ikke tilgået os nogen art af meddelelser om mulige nye planer.

I ærbødighed,

\section{Morten Bredsdorff.}

(Få dage efter overtages samtlige bygninger af et "krigslazaret" fra østfronten. $\mathrm{Ca} .1000$ hårdtsårede soldater anbragtes $\mathrm{i}$ lokaler og korridorer samt festsal. Epidemikere i elevhjemmet "Klostret«).

Mandag den 19. marts. Kl. 10 forhandling på mit kontor med Chefarzt og hans intendant. Jeg bad om at få Helligåndshuset frigivet og beskrev forholdene. Han lovede os at lade "das alte Haus« være frit. Snakkede i øvrigt om sine boligforhold, trængte til hvile, om der var plads i mit hus o. s. v. Jeg overhørte det og fastslog som resultat, Helligåndshuset frigivet ved mundtlig overenskomst.

it

Tirsdag den 20. marts. Om formiddagen kom Chefarzt og forlangte opfyring til om aftenen, da en "Einheit « var i vente. Jeg stillede krav om brændsel, intendanten sagde, at det ville han rekvirere på gasværket. Der kom ingen brændsel den dag, hvorfor han om aftenen gav lidt ondt af sig overfor pedellen, vi skulle ikke være så "mistrauisch $\ll$.

Onsdag kl. 9 standsede han mig i gården og bad om at få praktikklassen rømmet, vi var forberedt af en ytring herom dagen før, Eskildsen havde flyttet de tyske bøger $\mathrm{i}$ det store magasin. Nu skulle det ske omgående. Mein Kommandeur kommt heute, die Apotheke muss da hinein.« Jeg protesterede og mindede om vor aftale, men fik kun tilbud om hjxlp; Vi kommer med det samme og gør det selv. 
Så foretrak vi at bede S. II og S. IV om hjælp og ordnede flytningen; næppe var vi ude, før soldaterne begyndte at slæbe borde og flasker ind.

Jeg udbad mig derpå en klar udtalelse om læsesalen og borgestuen. Chefarzt var meget ulden, "vorläufig «, o. s. v. I øvrigt havde han rådighed over det hele, boliger o. s. v.

Det begynder at blive for broget, mine argumenter slides op, jeg er ene om sagen, ingen instanser her $\mathrm{i}$ byen hjxlper $\mathrm{i}$ mindste måde. Nu må jeg have hjxlp, ellers tager de det hele!!

Torsdag den 22. marts. Kl. 11 på amtshuset efter anmodning fra amtsskolekonsulent Svendsen og greven for at udtale mig angående nogle ansøgninger. Jeg benyttede anledningen til en livfuld skildring af vore vanskeligheder på seminariet og de fornyede trusler mod Riberhusskolen m. m. og beklagede mig over manglende støtte fra de danske myndigheder. Greven: »Synes De, vi gør for lidt herfra.« - »Der må kunne gøres mere, om ikke for andet, så for at sinke og besværliggøre disse planer, byen drukner jo, hvis alle disse folk, junkere, flygtninge og sårede kommer hertil «. Greven: „De har vist ret, man får $\mathrm{i}$ hvert fald ingen tak for at lade være med at gøre modstand".

Greven ringede derpå til Graf Schimmelmann i Haderslev, der står for indkvartering i Sønderjylland, og aftalte møde med ham fredag. På borgmesterens og mit forslag ringede greven desuden til Silkeborg og fik løfte om en repræsentant for stiftamtmand Herschend. Vi skulle så mødes i Haderslev fredag formiddag.

Fredag den 23. marts. Kl. 8,15 i luftværnets bil med borgmesteren til Schackenborg. Tyske soldater ved grevens private fløj, snavsede hoveder ud af riddersalen, invalider ud af hoveddøren, endelig kom greven gennem haven bag venstre fløj.

Dejlig køretur til Haderslev i opklarende forårsvejr. Kl. 10 i amtmandsgården, hvor vi traf fuldm. Lundsteen ${ }^{50}$ fra Silkeborg. Kort planlægning: Vi skal se at få tyskerne til at tale ud om deres planer, hvis de har nogen, hvad meningen er $\mathrm{i}$ Tønder? Vi vil have en udtalelse om de private boliger, dernæst prøve at redde: Helligåndshuset, Riberhus, Hedeselskabet m. m. Derpå i bil til »Kommandantur Südjütland«, Haderslev politigård, den er forskanset med 


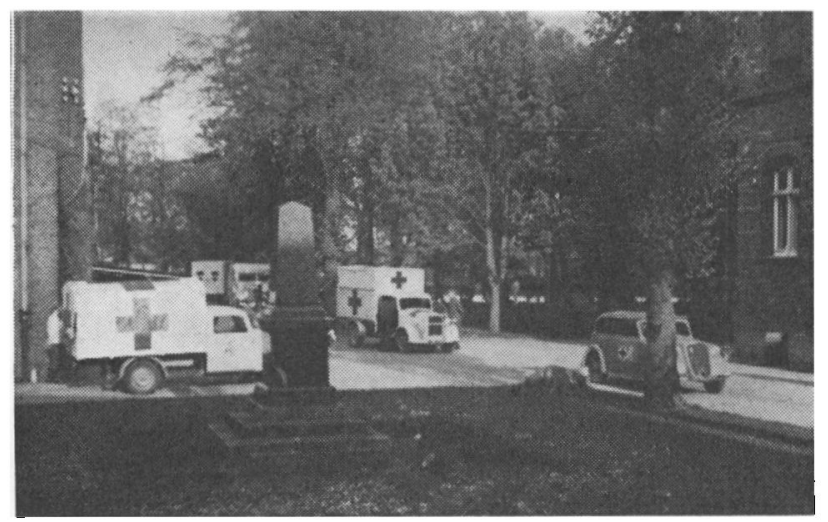

Tonder Statsseminarium omdannes til tysk krigslazaret, april 1945.

rusten pigtråd, vippebomme, skildvagter og maskingeværstillinger, rede til kamp. Med grev Schack $i$ spidsen slipper vi gennem alle spærringer og kommer op på 1 . sal ind $i$ en snavset ventestue med en klaprende skrivemaskinedame og to ventende officerer, der optager lokalets eneste stole. $\mathrm{Da}$ en oppasser går forbi, nævner jeg højt *Graf Schack og Bürgermeister Paulsen «, det vækker stor opmærksomhed, oppasseren bliver sendt ud efter stole, officererne og pigebarnet kigger interesseret på os, vi kommer alle til at sidde ned.

Så bliver vi kaldt ind til Oberst Graf Schimmelmann. Et stort lyst kontor med landkort og et vældigt Hitler-billede, meget sparsomt mobleret, åbent vindue til pladsen udenfor, hvorfra der jævnligt lyder forstyrrende skrålen og sang. En meget høj, let ludende aristokratisk herre, med krum næse og monocle for højre øje, hver gang han skal læse, det slår mig, at han med sit lidt verdensmandsmæssige ydre og et strøg af behersket kynisme påfaldende ligner en engelsk koloniofficer, overlegen, skødesløs og aristokratisk på en velgørende måde, meget lidt tysk type. Indtrykket forstærkes $\mathrm{i}$ dagens løb.

Vi slår os ned om et bord $\mathrm{i}$ hjørnet og opregner vore besværinger, Graf Sch. lytter tilsyneladende interesseret, rygende fine cigaretter med guldmundstykke. Borgmesteren taler om den almindelige bolignød $i$ Tønder, om officiantboligerne, Lundsteen erindrer om en overenskomst mellem værnemagt og den danske stat om ikke at røre danske officerers tjenesteboliger, såfremt deres familier fremdeles bebor. Graf Sch. nikker åndsfraværende, så får jeg ordet og skildrer 
seminariets vanskeligheder og taler for Helligåndshuset, hvis ærværdige ydre interesserer ham, da han får et billede forelagt (før 1940). Det går op for ham, at der er mange vanskeligheder $i$ Tønder, hvor stor er egentlig byen, 6000 indb. Ach, han mente den var meget større, der er jo åbenbart begået fejl ved belægningen i Tønder.

Så er der larm ude i ventesalen, en major kommer og melder nogle officerer. Graf Sch. nikker, lad dem komme ind. Ind kommer: majoren fra Junkerschule med sine to intendanter, grimme karle at se på, unge fanatiske nazister, den ene rødhåret, samt en lang grim officer, der viser sig at være Oberleutnant Sass fra Standort i Tønder. De herrer synes at stille til referat om deres bedrifter $i$ Tønder og for at få beslaglæggelserne $i$ orden, men vi er kommet først!

Graf Sch.: Hvad er det for noget roderi derovre i Tønder, Sass? Jeg har det indtryk af disse herrers udtalelser, at I er ved at overbelægge den lille by fuldstændig! Hvor mange flygtninge skal der endnu komme? Sass: Ikke flere til byen, men amtet kan endnu opsuge 1300! Graf: Men hvad skal så Junkerschule have? Major: Junkerschule kommer til Tønder på mandag og skal have følgende lokaliteter: Kasernen, officiantboligerne, soldaterhjemmet, gasværket, hangarer, Schweizerhalle, Hedeselskabet med alle privatboliger, markedshallen, exportstaldene, svendehjem, dragonstaldene, danske og tyske rohuse, Hotel Tønder komplet $\div 5$ værelser, Missionshotellet komplet $\div 5$ værelser samt CBU-skolen. Det er absolut minimum for Junkerskolen! Tønder-borgerne stirrer forfærdet på hinanden. Graf Sch.: Det var ikke så lidt, hvad skal lazaretterne have? Sass: Ortslazaret skal have *Tønderhus«, amtsgården, Alexandrineskolen. Krigslazaret seminariet, statsskolen, borgerskolen og Grand Café!

Graf: Hør Sass, det er vist noget roderi, De har lavet i Tønder, så meget kan der vist ikke være $\mathrm{i}$ den lille by, hvor skal man gøre af de mange familier. Lundsteen griber ind: Skal vi ikke først se på officiantboligerne, der foreligger jo et brud på en aftale. Lynende blikke fra nazisterne. Lundsteen: De herrer kender jo aftalen af 1940 angående danske officersboliger. Graf: Ja, hvad er det her for noget, hvorfor skal de officiantfamilier smides ud?

Sass med dirrende læber: Det er af militære grunde bydende nødvendigt, at de kommer væk. Sikkerhedshensyn kræver deres fjernelse, det er alt for farligt at have dem boende så nær. 
Borgmesteren rækker Graf Sch. kortet over Tønder, som denne studerer gennem sin monocle: Hør, ved De nu hvad, Sass, det er noget sludder, De står og siger, her må kunne oprettes et plankeværk eller et hegn. Sass: (hvid i ansigtet) - Herr Oberst, der er et plankeværk, men der er lavet et stort hul i det, som klart viser faren ved at have disse folk der. Graf: Kan De sige mig, om det hul er lavet af de tyske soldater eller af de danske børn, som formodentlig render og leger derude. Sass: Herr Oberst, det er ikke let at afgøre, dog synes hullet lavet fra vestsiden. Graf: Nå, så se at fă lukket det hul og hold det $\mathrm{i}$ orden, der er ingen mening $\mathrm{i}$ at smide de familier ud. Her består jo en aftale.

Den rødhårede intendant griber ind: Herr Oberst, et ord, der blev givet $\mathrm{i} 1940$ har ingen som helst gyldighed $\mathrm{i}$ dag overfor danskere!

Graf (banker $\mathrm{i}$ bordet): Så, så, min herre, en aftale, der er indgået mellem værnemagten og den danske stat, respekterer jeg. De officiantfamilier forbliver $\mathrm{i}$ deres huse. Har De forstået! Jawohl, Herr Oberst! Graf: Så er der Hedeselskabet, behøver vi at smide de familier ud! Major: Absolut nødvendigt, militære grunde! Det er en skole, der skal være lærere, strateger og taktikere, de skal ud! Graf: Nå, kan De ikke nøjes med at tage lokalerne nedenunder? Major: Ikke tale om. Graf: Hvor skal de familier og andre hen? Borgmester: Vi har stor bolignød i Tønder, vi kan ikke tage imod flere! Major: $\mathrm{H}^{\circ}$, jeg kender Tønder, der er en forhistorisk boligkultur $\mathrm{i}$ Tønder, hver familie har et hus, der står et tomt hus nede bag dr. Brenners villa, se bare efter, hr. borgmester, De finder nok flere. Tyskland står i Abwehrkampf um Europa, i den yderste nød. Vi kan ikke tage alle disse latterlige hensyn!

Den rødhårede intendant: Der er overhovedet ingen grænse mere mellem Danmark og Tyskland, når man ved, hvordan der leves $\mathrm{i}$ tyske byer, er der ikke fjerneste grund til, at danske byer skal have det et hår bedre, der kan bo 5-6 gange så mange mennesker i Tønder, med lidt god vilje, ellers kan de rykke ud på landet. Deutschland steht im Abwehrkampf o.s. v. Graf Sch. ser ud i luften med et minespil, som i romanerne gengives ved: Bah!!

Graf Sch.: Det kan aldeles ikke nytte at jage folk ud af deres huse, det loser ingen problemer, det er heller ikke hærledelsens mening. Jeg hører nu af disse folk, at der er stor bolignød i Tønder. Sass, det skulle De have tænkt på i tide, i stedet for dette her svineri, 
nu brænder det hele sammen, det er Deres skyld. "Jawohl, Herr Oberst! «

Graf: Major, kan De intet undvære?

Major: Herr Oberst, det hele er jo midlertidigt. Om 10 dage ankommer vore barakker, de kan rejses på et par dage, så rykker en del af junkerne derud, og så kan man frigive visse bygninger $\mathrm{i}$ den indre by.

Lundsteen skriver op og siger: Disse barakker kommer altså om 10 dage. Den rødhårede intendant: Lad være at skrive det tal op, vi vil ikke høre det igen, de er på vej, men det kan vare både 3, 4 og 5 uger eller mere. Graf: Skal så familierne sættes midlertidigt ud af den grund? Borgm.: Vi har ingen pladser; noget af dette må frigives. Major: Så kan De få exportstaldene, hr. borgmester, man kan jo dog ikke behandle soldater som kvæg.

Graf: Det her er ikke godt. For det første står fast: Officiantboliger og øvrige privatboliger må ikke krænkes uden ganske særlige grunde, de nævnte skal lades i fred i Tønder. De har lavet det skidt, Sass! Jawohl, Herr Oberst. Jeg vil selv komme til Tønder i morgen og se sagerne »an Ort und Stelle«, jeg skal ikke glemme Deres seminarium, dette her må vi have ordnet. Und dann - en elegant håndbevægelse til officererne - Heraus! De fjerner sig med voldsomme bevægelser, oprakte arme og gjaldende Heil!

Efter de fire officerers larmende afskedsscene vendte Graf Sch. sig nonchalant til os danske borgere og fortsatte forhandlingerne, nu assisteret af sin egen major, en ret gemytlig rundhovedet mecklenburger (formentlig), som præsenterede sig som "Standortälteste" $i$ Haderslev - og hvem vi senere enedes om at kalde "Major Bræsig".

Borgm.: Jeg har det indtryk, at majoren er ausgeschaltet og slet ikke tager del $i$ tilrettelægningen af disse sager.

Forst.: Da Junkerskolen forlod seminariet den 12. marts, henviste man mig til Standortkommando for der at få oplysninger om, hvad der videre skulle ske med seminariet, og især med en familie, som var beordret ud af en tagetage. Jeg talte i telefon med 5 forskellige personer, men ingen vidste besked eller kunne give mindste oplysning.

Graf Sch.: Hm, det er nok bedst, jeg selv tager en tur til Tønder for at undersege forholdene »an Ort und Stelle«. Kan det passe de herrer $\mathrm{i}$ eftermiddag for eksempel? 
Grev Schack: Vi er rede, når det skal være.

Graf. Sch.: Ja, jeg må hellere tage Oberregierungsrat Dr. Haensch fra Aabenraa med, så kan vi sammen drøfte sagerne.

Mens Graf Sch. telefonerer til Aabenraa, henvender majoren sig til borgm. og mig: Ser De, mine herrer, her i Haderslev har vi en fortrinlig ordning. Når vi kommer med vore krav, har borgmesteren altid nogle modforslag parat, lagerrum, pakhuse, ubenyttede lokaler o. 1. Der kan som regel findes en fornuftig ordning. Må jeg bede Dem, inden vi kommer til Tønder, lave en fortegnelse over de objekter, som her er blevet krævet, og så opstille eventuelle modforslag.

Borgm.: Vi har intet til overs.

Major Bræsig: Officielt næppe, men uofficielt finder De nok noget!

Så er Graf Sch. færdig med at telefonere: Dr. Haensch kan først i morgen lørdag, kan det passe de herrer f. eks. kl. 10,30?

Greven: Udmærket, mødet kan finde sted på mit kontor på amtshuset.

Graf Sch.: Så er det en aftale, vi kommer i morgen og fortsætter forhandlingerne. Vi slutter med at udtrykke håbet om resultater og minder endnu en gang om, at Tønder er en meget lille by; jeg tillader mig $i$ denne sammenhæng at betegne den som en Dorf, der allerede er delvis overfyldt.

Afsked, vi finder vej ud af den svært befæstede politigård og tager ned til amtsgården, hvor amtmand Pinholt netop skal have amtsrådsmiddag, hvortil vi alle tre venligst indbydes. Forhandlingerne har varet små to timer. Det aftales derpå, at Lundsteen skal komme til Tønder i morgen og deltage i mødet på stiftamtmandens vegne (Silkeborg).

På hjemvejen i bilen, hvor vi bl. a. drøfter grænseproblemer o. l., er vi enige om, at det eneste positive resultat er tilsagnet om officiantboligernes ukrænkelighed, samt de øvrige privatboliger, og så naturligvis dette, at manden selv kommer til Tønder. Det kan der komme noget ud af!!

Lordag den 24. marts. Strålende solskin. $\mathrm{Da}$ jeg $\mathrm{i}$ går efter min hjemkomst fra Haderslev kl. ca. 16,30 pludselig så den lille junkermajor $\mathrm{i}$ seminariets gård, beslutter jeg at tale et ord med Chefarzt 
først. Jeg beder pedellen melde, når han kommer; dette misforstår Frandsen og kommer kl. 9,30 til mig med den besked, at forstanderen kan selv komme over på hans kontor. Tonen er altså lidt anderledes end de første dage, men det kender man jo. Det viser sig, at han har kontor $\mathrm{i}$ tandlægeværelset med vagt udenfor og intendanten ved sin side derinde. Jeg spørger ham, om vi kan få en klar aftale om Helligåndshuset, som seminariet ikke kan undvære. Han afviser dette, "Vorläufig" vil han slet ikke udtale sig derom, "mein Kommandeur kommt bald, « han bestemmer det hele! Der er ingen vej frem. Da jeg viser ham det officielle beslaglæggelsesdokument, og med hjemmel $\mathrm{i}$ dettes sidste punkt anmoder om en liste over det overtagne inventar, benytter han lejligheden til at påstå, at han råder over det hele, også de private lejligheder. Jeg gør ham opmærksom på, at disse ikke er nævnt i dokumentet, og hævder, at hans opfattelse må bero på en misforståelse. Klare udtalelser fra Silkeborg går i stik modsat retning, "Ja, nu skal vi se, nu har jeg ikke mere tid, schön, schön!«

Det er åbenbart på tide, at han bliver bremset, ellers tager han det hele, nu får vi se, han er en typisk plebejer og næppe videre begavet.

K1. 10,30 er jeg på amtshuset, Lundsteen er lige kommet, vi står sammen med greven og borgmesteren $i$ den lille amtsrådssal, hvor greven for tiden har kontor. Det må i dag gælde at få en ordning, helst skriftlig, med magthaverne, vi begynder med de private boliger, så skolerne, så får vi se...

Så kommer Graf Schimmelmann, han indleder en let samtale med grev Schack om portrætterne af de gamle amtmænd og landråder, "Dette er Brockenhuus-Schack, der måtte forlade embedet i største hast «, siger greven. Wann? I 1864! Aha, ja naturligvis, 64! Og hvor længe har De selv været i dette embede? 40 år i amtsrådet, deraf 25 år som amtmand, siger greven, og denne replik kaster et fornøjeligt perspektiv over denne formiddags hændelser. Mens de to grever konverserer let og naturligt, smækker døren op, og ind kommer en lang, tynd officer, med stærkt tilbagevigende pande, fremstående hage, fanatiske brune øjne, Oberregierungsrat Dr. Haensch. Det er tydeligt nok en beregnet entré, der røber hans forfængelighed, en yngre partimand, der er gået hastigt og lige tilvejrs, og derfor noget usikker i sin optræden. Med stiv nazihilsen iler han frem som på en 
scene, han ser åbenbart kun uniformerne, lige hen mod Graf Sch., der med en elegant håndbevægelse gør ham opmærksom på, at han er faret lige forbi grev Schack, hvem Graf Sch. nu skynder sig at præsentere. Så hilser dr. H. flygtigt på os andre inferiøre personer, og vi sætter os om det runde bord - der rigtignok, som det skal vise sig, ikke er noget round table - og forhandlingerne begynder.

Graf Sch.: Ja, ser De, dr. Haensch, det er disse belægningsforhold i Tønder. Man har åbenbart ganske forregnet sig $\mathrm{m}$. h. t. byens størrelse, jeg har en gang tidligere nævnt det for generalkommandoen i Silkeborg, men man ville åbenbart ikke rette sig efter mig. $\mathrm{Nu}$ er det ved at gå rent galt. Han nævner derpå, med forbløffende hukommelse, de vigtigste af de sager, som vi om fredagen har forelagt ham. Derpå omtaler han mere detailleret officiantboligerne. De ved, kære dr., der er en aftale om disse danske officersboliger, nu påstår rigtignok disse junkere, at militære grunde kræver deres rømning. Jeg kan nu ikke indse, at dette er nødvendigt, der må kunne laves en afspærring, så disse folk kan blive $i$ deres huse, for denne aftale skal respekteres, derom er vi da enige.

Dr. H.: Fuldkommen, hr. Graf!

Grev Schack: Så er der skolevæsenet, må jeg have lov at sende bud efter amtsskolekonsulenten, så vi kan få de nøjagtige tal her $\mathrm{i}$ byen. (Jeg skynder mig ud og henter Svendsen, der sætter sig ved siden af mig, og deltager $i$ resten af forhandlingerne).

Vi tager nu - af taktiske grunde - den tyske skole først, idet dr. Haensch udtaler, at han grundsätzlich står på det standpunkt, at der skal herske Parität mellem tyske og danske borgere i disse byer! Man enes om, efter at der er blevet indrømmet de tyske lærere ret til at beholde deres lejligheder i Alexandrineskolen, at denne skole i øvrigt skal rømmes totalt og overlades til andet brug. Graf Sch. foreslår derpå, efter at have set et billede af den tyske kommuneskole $i$ et særtryk af "Tønder gennem Tiderne", at det tyske skolevæsen ialt făr 4-5 værelser i kommuneskolen, dette til 150 børn. Derpå oplyser vi ham om, at alene den danske folkeskole har 413 børn, der må altså skaffes meget mere.

På dette tidspunkt beklager "major Bræsig «, at borgmesteren har glemt at opstille modforslag, at komme med andre objekter i stedet for dem, man ønsker frigivet. Borgmesteren: Vi har ikke noget at byde, bolignøden er meget stor. Han støttes af stadsbygmesteren, 
som også er tilstede, denne oplyser forskelligt om de for tiden husvilde familier $\mathrm{i}$ Tonder.

Graf Sch.: Jeg kan se på Dem, hr. seminariedirektor, at De er ved at blive utålmodig. Jeg har ikke glemt Deres skildring af seminariet i går, og vi skal nok komme til seminariet og den danske skole.

Kort efter får jeg ordet for at redegøre for det danske skolevæxsens stilling, seminariets ønske om Helligåndshuset, Schweizerhalle, som ikke på nogen måde kan undværes til folkeskolen, Hedeselskabet, som ligeledes er nødvendigt for os. Borgm, støtter kraftigt.

Der fremlægges billeder af Helligåndshuset, grev Schack forklarer, at bygningen er fredet $\mathrm{i}$ klasse $\mathrm{A}$, han oplyser, hvad dette betyder, og dr. Haensch gentager for Graf Sch., fredet i klasse A, (B og $\mathrm{C}$ o. s. v.), det går rigtig godt. Jeg beklager tabet af praktikværelset, men det er nu apotek, det lader vi gå, når vi blot kan redde det gamle hus. Major Bræsig ser på billedet: Jeg kan ikke begribe, hvad glæde de lazaretfolk kan have af det gamle hus, der er tjenesteboliger nedenunder, besværlig adgang, det synes jeg, man skulle overlade skolen.

Graf Sch.: Ja, det synes jeg virkelig også.

Forstanderen: Ja, for vi tør jo efter de faldne udtalelser regne sikkert med privatboligernes ukrænkelighed. Graf Sch.: Ja, dem tager vi ikke. Og skal de f. eks. flyttes af militære grunde, fordi de ligger midt inde $\mathrm{i}$ et kompleks, så skal der ydes en tilsvarende lejlighed i samme by.

Lundsteen: Det er en meget vigtig udtalelse. Vi har utallige klager i Silkeborg, bl. a. fra højskoleforstandere, hvis boliger man vil have.

Graf Sch.: Ja, det er en fejl ved disse beslaglaggelsespapirer, at de ikke indeholder et klart forbehold om privatboliger, det er vist for øvrigt min egen fejl. Vi skal se at få det rettet. Det er ikke meningen at tage boliger fra fastboende (ortsansässige), når de selv bebor dem. Lader de dem stå tomme, er det en anden sag. - Men nu tilbage til skolerne, vi var ved seminariet.

Jeg omtaler den forestående eksamen og dens krav, så griber Lundsteen ind, og nu springer dagens bombe!

Lundsteen: Seminariet burde have noget mere plads. Det er jo en højere skole, og ifølge Haager landkonventionen må en sådan overhovedet ikke røres...! 
Længere kom han ikke. Så slår dr. Haensch i bordet, springer op og råber rasende: Hvis De vover at kaste Haager konventionen ind i debatten, så er det hele forbi med det samme! De har komplet misforstået situationen, når De mener, at her skulle være tale om nogen som helst rettigheder. Nævner De dette én gang til, er forhandlingerne afbrudt med det samme! Vi er her, imod vore principper, af nåde, for at se, om vi måske kan give Dem visse indrømmelser, men De skal bare vove at stille fordringer! Danmark, der daglig overtræder Haager konventionen med mord, brand og sabotage, har intet at påberåbe sig o. s. v., o. s. v....!!!

Han er rød i hovedet og råber, på en eller anden måde står vi alle op fra vore pladser, ivrig gestikuleren og protester, Graf Sch. fortrækker ikke en mine og tier bomstille, indtil udbruddet er ovre. Så sætter vi os efter denne kostelige og højst interessante scene, Lundsteen har bemærket, at han er jurist og interesseret i principper, nu pustes der tobak fra de fleste munde, og man prøver at falde til ro. Grev Schack siger, at vi er her vel ikke så meget for at drøfte principper, hvad der vel nxppe kommer meget ud af, som for at opnå resultater, og ved de to grevers hjxlp overstås det pinlige (festlige!) optrin, og forhandlingerne kommer igang igen. $\mathrm{Nu}$ er vi ved Schweizerhalle og Hedeselskabet, det ser ud til, at vi skal have begge dele, vi venter på dette tidspunkt noget $i$ retning af en skriftlig overenskomst, der skal frigive visse bygninger fra beslaglæggelser. Det nævnes af Lundsteen, at CBU-huset i Spikergade, som der er beslaglæggelse på, er en luftværnshistorie, så skal den også frigives, seminariet skal have Helligåndshuset, det går rigtig godt.

$\mathrm{Da}$ banker det på døren, og ind kommer Chefarzt fra seminariet med intendant, stor nazihilsen mellem de uniformerede, vi ser til, når man har set det på næert hold et par dage, synes det at ligne en eller anden negerstammes mærkværdige etnologiske sædvaner, værd at optegne for den rejsende, men et stykke udenfor civilisationen.

Uniformerne mumler lidt indbyrdes, og Graf Sch. beder grev Schack om tilladelse til at gå ind i sideværelset for at forhandle separat. Alle tyskerne forsvinder ind i det uopvarmede amstrådsværelse, og vi drøfter stillingen, jeg frygter svære tilbagefald, men nu må det hele ske under eet. Vi glxder os over de klare og højtidelige tilsagn om privatboligernes ukrænkelighed, nu kan vi vel få fred 
i 8 dage og holde påske, og det er allerede noget at vinde 8 dage på dette tidspunkt af krigen.

Lundsteen og jeg samtaler om betydningen af at holde hjemmene fri, det styrker den moralske modstandskraft, måske mere end noget andet, ligesom opleste og omflyttende hjem er spiren til mismod og opløsning, nu har de noget at benytte i Silkeborg under kommende skænderier.

Det varer ret længe med tyskerne, kl. var ca. 11,45, da de forlod os, og først over 12,30 kommer Graf Sch., dr. Haensch og Major Bræsig igen. Lxgerne er sendt hjem.

Graf Sch. ser noget deprimeret og træt ud, han begynder med at forklare, at sagerne er mere komplicerede, end han troede, lazaretfolkene er i nød, de mangler plads til sygeplejerskerne og lægerne, der skal intet rokkes ved de afgivne udtalelser om privatboligerne, men hele spørgsmålet er så omfattende, at det må forelægges generalkommandoen i Silkeborg til endelig afgørelse. Jeg puffer til borgmesteren, der så indskyder: Kunne vi ikke komme af med Junkerskolen, det er jo derfra, alle vanskelighederne kommer, er den væk, kan vi vel nok skaffe plads til lazaretterne. Forst.: Ja, det er sagens kerne, Junkerskolen bør bort fra Tønder! Graf Sch. (smiler): Ja, jeg har forstået, at de herrer ikke er forelskede i Junkerskolen, det behøver De ikke at forklare mig, og det kan jeg såmænd godt forstå. Men jeg er ikke almægtig, og der er stærkt pres på fra Berlin og andre steder.

(Vender sig til dr. H.): Ikke sandt, vi kan uden forbehold bekræfte vore udtalelser om boligerne. Dr. H.: Fuldkommen enig!

Graf Sch.: Men det øvrige må om ad Silkeborg, og længere kan vi ikke komme denne gang!

Borgm.: Så siger vi tak for de faldne udtalelser, det er en stor beroligelse, at man vil lade private boliger $\mathrm{i}$ fred, det regner vi som en afgjort sag. Vi takker for forhandlingerne og håber, at der ved den fortsatte drøftelse må komme resultater, der nogenlunde ligger på linje med de ønsker, som vi i dag har kunnet fremsætte, således at også skolearbejdet kan fortsætte her $\mathrm{i}$ byen.

Man rejser sig og tager formel afsked.

Foran amtsgården holder 4 biler, en fra indenrigsministeriet (Lundsteen), luftværnschefens bil fra Tønder (efter grevens onske, for at ingen af os skulle blive nødt til at gå $i$ en tysk bil, såfremt 
det ville være blevet nødvendigt at køre ud og se på lokaler og bygninger), og 2 tyske militærbiler, bevogtet af sorte SS-folk. Ovre på »Tønderhus« hejser de Røde Kors-flaget, klokken er 13,10.

Palmesøndag forløber i ro, Chefarzt passer sig selv, men da han ud på aftenen ser mig $i$ lang afstand, jeg står $i$ haven lige under vort flag, hilser han særdeles høfligt. Han har nok fået en omgang, og holder sig nu på måtten - indtil videre.

Tirsdag den 28. marts. Kl. 9,45 møder jeg Eskildsen, da jeg kommer ud fra en time med S. III på Hedeselskabet. Han meddeler mig fra borgmesteren, at Oberleutnant Sass og Major Freydank er sendt til fronten. - Helt spildt har den Haderslev-tur alligevel ikke været!

Lørdag den 21. april. Kl. 8,30 efter morgensang fik jeg af frøken Horsbel at vide, at en transport af danske internerede, vistnok fra Kolding, skulle passere Tønder $\mathrm{H}$. i formiddagens løb på vej til Frøslev, da Østbanen er afbrudt ved Sommersted. De skulle, hvis tilladelse opnåedes, bespises af Røde Kors. Da min bror ${ }^{51}$ muligvis kunne være med, tog jeg kl. 9 ned på banegården og meldte mig hos formanden fru Atke som tolk og hjælper, blev udstyret med armbind og hjalp i øvrigt bagermester Sv. Petersen ${ }^{52}$ og nogle DKBdamer ${ }^{53}$ med at lægge boller på bakker, ordne madpakker, kaffekopper, tobak o.s.v. Ca. 9,30 kom en meget lang tysk transport for sydgående. Den forsinkede det tog, vi ventede, så det næppe ville komme for 10,30. I mellemtiden sendte vi for alle tilfaldes skyld bud efter dr. Jepsen.

Kl. 10,35 kom et langt dansk godstog ind. Transporten befandt sig i nogle af de forreste vogne. Vi måtte langt ned ad baneterrænet for at træffe "Transportenführer «, hvem jeg bad om lov til at bespise vore landsmænd. Han gav mumlende tilladelse, men kun for Røde Kors-folk. Fangerne befandt sig dels $i$ en godsvogn, der rummede 55 mand, dels $\mathrm{i}$ en kupé med tillukkede vinduer 11 mand og en kvinde, de øvrige kupéer var optaget af vogtere, $25 x$ ldre tyske gendarmer.

Vi hentede nu de smurte boller, frk. Horsbøl og frk. Enemark ${ }^{54}$ kom med kaffe i spande, portene lukkedes op for den store godsvogn, og her stod de 55 mand, såvidt man kunne se mest yngre københavnske arbejdere, tæt op ad hinanden. Adskillige var noget fængselsblege, de halvfrøs i den kolde luft, men muntre og zünftige 
bemærkninger haglede straks. "Sommeren er nok osse rationeret $i$ Tonder! « *Vil I have kaffe! * $* \mathrm{Ja}$, det kan I lige tro, vi vil! $*$ Hvor længe har I siddet? " Lige fra 14 dage og op til et halvt år, alle i Vestre Fængsel.* (Altså ikke fra Kolding). "Var det slemt? « »Når forhørene var overstået, gik det rigtig godt «. Så fik de boller og kager, kaffe i spandevis og derpå cigaretter. Jeg bød også Transportenführer og hans folk, de takkede og trak sig høfligt tilbage, hvorefter der kunne gives lidt mere intime meddelelser og også afleveres adskillige hilsener. Inde $\mathrm{i}$ kupéen sad de lidt $x$ ldre og en kvinde; her traf jeg overlæge Collin fra Gentofte, vi forestillede os for hinanden, «jeg er dømt til 10 år

"Så er det godt, De skal blive i Frøslev.« "Ja, det er jeg meget glad ved." En yngre mand fortalte, at han i samme anledning havde

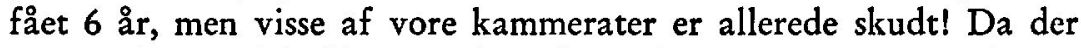
var rigeligt med kaffe, gav vi også gendarmerne en kop med. Det forbedrede yderligere situationen, og der blev efterhånden livligt, hurraråb lød ud over baneterrænet, hvorfra dog alle »Zivilisten " var blevet jaget vak lige fra begyndelsen. Godsvognens indbyggere fortalte, at de havde rejst siden onsdag morgen! Om natten kunne halvdelen af dem ligge ned, mens de andre stod langs væggene, det var ret drøjt, én toiletspand $i$ hele vognen. »Man troede ikke, at Danmark var så stort! « Tilsidst fik de madpakker, som var tilvejebragt bl. a. af husmoderforeningens medlemmer. Så ville Transportenführer lukke dørene, de raske gutter istemte gjaldende hurraråb for Tønder. "Vi kommer snart igen, vi har returbillet allesammen, det varer højst 14 dage!!« Så kom et gribende øjeblik, de 55 istemte alle $\gg$ Der er et yndigt land - . Vi blottede hovederne, tyskerne masede med de tunge skydedøre, som først gled helt $i$, netop da det lød: „Og gamle Danmark skal bestå — —. Så sang de videre $\mathrm{i}$ den store kasse, mens fingre vinkede ud af tremmerne under taget. "De kan knække alt, men de kan sgutte knække humøret! « lød det derindefra.

Så gik vi op i kupévognen og tog afsked. Her gjaldede nye hurraråb, og så istemte vi alle "Det haver så nyligen regnet - *, fanger og vi andre, mens de mutte tyskere så forundrede til. Transportenführer kom hen og sagde tak, fordi vi også beværtede hans folk. *Så skal De til gengæld være god mod vore landsmænd, til De afleverer dem i Faarhus«. "Vi skal ikke gøre dem noget ondt! «, sagde 
han, og vi havde i øvrigt det indtryk, at der herskede et ret gemytligt forhold mellem begge parter undervejs.

Vi forlod stationen, grebne og opmuntrede. Først kl. 13,30 skulle toget afsted til Tinglev, det ville blive aften, før de nåede Frøslev. Men de drog ikke sultne fra Tønder, og vi havde fàet rigelig belonning.

Onsdag den 25. april. Flere af seminarieeleverne har i de forlebne dage lejlighedsvis begivet sig til Krusaa for at overvære hjemvendende tysklandsinterneredes ankomst, i første rakke deres egne 5 kammerater, ${ }^{55}$ der nu alle er kommet over grænsen, 3 til Sverige, 2 til Frøslev. Jeg ville selv så gerne en tur derned, men trafikforholdene er meget vanskelige, så jeg griber med glæde til, da ingeniør Claudi-Westh kl. ca. 10 ringer og indbyder mig til at tage med $i$ en bil, som på Jordlovsudvalgets vegne skal til Frøslev. I hast aflyses eftermiddagens planlagte lærerrådsmøde, Friedy får fat $i$ en pakke levnedsmidler til Sydslesvig, som vi skal tage med, og kl. 11 kører vi fra Tønder, ing. Westh, amtsrådsmedlem Hørlück, lektor Kiørboe $^{56}$ og jeg; desuden frk. Schibler, ${ }^{57}$ som skal til Tinglev.

Undervejs aflægges besøg $i$ en gård $i$ Bodsbøl, hvor konen fortæller om de tyske jernbanevagters udtalelser om, hvad der vil ske, når Berlin er faldet og en vis mand måske med; så løses de fra faneeden, og så... Kl. 14 ankommer vi i strålende sol til Krusaagård, hvor de venlige værtsfolk, forpagter Petersens, byder på middag. Her er alt præget af store, men improviserede forberedelser. I gården står lange spiseborde og bænke, $\mathrm{CB}$-mænd færdes allevegne, talrige DKB-kvinder under ledelse af frk. Reppien ${ }^{58}$ og andre får instruktion $\mathrm{i}$ gården eller ankommer med de hvidmalede rutebiler. Man venter 3-400 franske internerede $i$ eftermiddagens løb. Vi beser de fire barakker og hilser på lederen, oberstløjtnant Hintze, tidl. Søgård, og nogle af hans folk. 2 barakker til spisning, 2 med halm til overnatning, de øvrige 4 er taget til brug i den overfyldte Frøslevlejr, men savnes hårdt her. Hr. Hintze fortæller lidt om de utrolige og forfærdelige ting, som fangerne har berettet eller båret vidnesbyrd om på deres krop, det sidste hold blev mandag eftermiddag indladet $\mathrm{i}$ tog $\mathrm{i}$ Padborg, men kom tilbage, da der var udbrudt strejke i Fredericia på grund af de sidste henrettelser. Så måtte man have dem næsten et døgn længere. 
Vi fortsætter turen ned mod Kobbermøllen, betragter den lange tankgrav og andre improviserede spærringer, der ligesom visse iagttagelser undervejs bekræfter det indtryk, at her påtænkes et vist forsvar. Lektor Kiørboe foreslår mig en tur ad Gendarmstien til fjorden, og da vi har det indtryk, at Jordlovsudvalgets medlemmer alligevel har forretninger, og der næppe foreløbig kan ventes ankomst, går jeg med, da jeg aldrig for har været den tur. Den var sjældent smuk, og det var interessant på det lille stykke af Flensborg fjord, der herfra er sigtbart, at txlle hen mod en halv snes store dampere på svaj, en enkelt lå overskåret på midten inde på grunden, hjemsted Hamburg, 4-5 u-både og en stor fuldrigger. Men vi havde nær fortrudt det, da vi kom tilbage, thi imens havde ingeniør Westh besøgt karantæenen og truffet flere franskmænd. Ved hans hjælp kom vi nu hastigt derned, karantænen er indrettet i Mollehuset, her lå en 25-27 franske kvinder til sengs under primitive forhold. Amtslæge Lausten-Thomsen er netop derinde, han byder os indenfor, jeg betragter de furede og afmagrede ansigter, enkelte stærkt forslåede, nogle er ved at skifte linned, radmagre rygge, flade bryster, blålige lasioner flere steder. Midt iblandt sengene bliver vi stående, idet amtslægen præsenterer os for en yngre fransk dame $i$ hvid kittel. Hun fungerer som hjxlper, madame eller mlle. Martel fra Cognac. Et skarpt, meget intelligent ansigt, brændende øjne, et hærget, men meget karakterfuldt ydre, hun begynder straks at fortrlle. Ordene strommer fra hende, et voldsomt indre pres, vi behøver blot at støtte med enkelte udbrud af deltagelse eller forfærdelse eller opmuntring, hendes øjne hænger ved den lyttende, det er hende usigeligt magtpåliggende at få lov at berette. Her er hovedtrækkene af denne uforglemmelige skildring:

27 måneder $\mathrm{i}$ kvindelejren Ravensbrück, nord for Berlin, vistnok verdens største kvindelejr, plads til 110.000 , almindeligvis belagt med 60-70.000 kvinder. Politiske fanger kaldtes de, mange af dem var ammunitionsarbejdersker, af de herværende var de fleste fra Paris eller omegn ført til Tyskland for år og dag siden. Ernæringen var utrolig slet, avitaminøs suppe som vand, snavsede rødder, sammenkogte og udkogte sager. Op kl. 3 eller 4 om morgenen, hårdt arbejde, slæbe sveller og bjælker, ammunitionsfabrik, sy sækkelærred eller lign. Slag og spark, når arbejdet gik for langsomt, om formiddagen 3 timers appel med bare ben $\mathrm{i}$ sne og pløre, alle skulle 
stå ret på en stribe, blodhunde nappede de usikre i hæle og lægge. De kvindelige vogteres plagerier frygteligt udspekulerede, straffene brutale, og de idømtes for den mindste uregelmæssighed, næsepudsning $\mathrm{i}$ utide, tabte sager eller lign. Ikke sjældent indtraf fødsler under appellen, de skulle tilendebringes stående, ingen måtte hjxelpe den fødende. Børnene blev straks bragt til gaskamrene. Ingen turde melde sig syg. Alle farlige eller epidemisk syge blev bragt til gaskamrene og aflivet, tusinder drabt på denne måde. Mlle. Martel havde overværet en straffescene, pisk, afklædning, slag, derpå vanddrikning til bugen stod som en tromme, så boksestød i maven til alt var gylpet op, derpå slag og bevidstløshed.

Selv var hun sammen med andre yngre nogenlunde velskabte kvinder flere gange ført til de ledende gestapochefer, der stillede kyniske forslag, mishandlede de unge kvinder, afklædte og voldtog dem. Hun fremviste dybe ar på højre arm fra et sådant tilfælde. "Mine herrer, det kræver enorm kraft at modstå sådanne ting, det er den højeste prøve på ens moral.« Jeg: »De har jo været $i$ barbarers hænder! « "Monsieur, det er ikke barbarer, det er sindssyge stakler, mennesker med angst- og mindreværdskomplekser, mareredne af frygt $\%$.

K.: "Er det rigtigt, som fremhævet $\mathrm{i}$ radioen, at tyskerne spekulerede $i$ at splitte og dele fangerne og sætte dem indbyrdes op mod hinanden? « Martel: »Nej, egentlig ikke. De moralske skavanker i fangernes samfund stammede fra os selv, slette kammerater, menneskelig lavhed og usselhed, der udøvede et indre moralsk tryk på os alle. Tyskernes tryk var i grunden kun fysisk, mere kunne de ikke. Men vi har oplevet utrolige ting!! Min familie kender og omgikkes de Gaulle, derfor troede de, at jeg var spion, jeg har været dømt til døden en tid, men blev benådet. Jeg håber snart at være hjemme igen, måske kan man hente mig med Avion fra Frankrig, når jeg bare kommer til Sverige! - *

En uforglemmelig illustration til denne uforglemmelige samtale var de stakkels kvinder rundt om i sengene, som netop nu blev vasket og fik skiftet. De syntes at antage os for læger og var ugenerte af vor tilstedeværelse. Modsætningen mellem dem og de blomstrende, runde danske plejersker sagde mere end ord.

Vi tager afsked med mlle. Martel og håber på gensyn i Frankrig. 
Hun strømmer over med taksigelser til Danmark, amtslægen minder hende om, at det er en svensker, ${ }^{59}$ hun skal takke, ikke os.

Der er stadig ingen flygtninge $i$ vente, og alt er usikkert, da man ingen efterretninger kan få. Vi skal derfor snart afsted, da bilen skal hjem. Vi går op på højen ved barakkerne. Her sidder tre unge franske damer, som vi hilser på, en ung pariserinde, frisk og blond, en mørkhåret dame fra Lyon, men født polak. - "Jeg har hørt om mødet i San Francisco, tror De ikke nok, man begynder med Polen? ${ }^{60}$ - en dame fra Tours, født i England og engelsktalende. Med den sidste samtaler vi bedst, de andre lytter til. De kommer alle fra Ravensbrück, a wonderful place! Og de bekræfter mlle. Martels beretninger og føjer mere til, $f$. eks. om en nonne, som frivilligt fulgte skrigende og fortvivlede patienter i gaskamret - thi Gud er jo allevegne! Min mand er desværre $\mathrm{i}$ Oranienburg endnu. K.: »Ved De ikke, at Oranienburg er befriet? " "Af hvem? " Af russerne.« "A h, havde det bare været de andre.« "Er man bange for russerne? " "Ja, vi var i dødelig skræk alle i lejren, tyskerne fortalte os, at russerne ville behandle os meget værre, og vi ville alle komme til Sibirien.* "Troede de virkelig dette? " Ja, det troede vi alle." - Hun fortæller, at tyskerne blev hysteriske under luftangreb - "men vi sang Marseillaisen, så det klang, for at opmuntre flyverne«. "Det gjorde vi også $\mathrm{i}$ toget til Lübeck, hvor vi havde 4 timers airraid, men intet kunne se, da der var brædder for alle vinduer. Vi så intet til det skønne Tyskland! Men det kan også være det samme, nu må det land forsvinde fra landkortet! « Solen skinner forårsskønt over udsprungne bøge ved Krusaa. "Dette er det skønneste sted $i$ verden «, siger damen fra Tours, wher føler vi friheden og livet igen. Folk smiler og hilser, de sparker og slår os ikke, når vi møder dem. Det er vidunderligt « Så skal vor bil afsted, vi må sige au revoir en France! De stråler af glæde. Og vi kører hjem, rystede i vort inderste, og samtidig oplivede af disse indtryk af ukuelig livskraft og tapper kvindelighed.

En mærkelig dag er endt.

Torsdag den 3. maj. Rygterne har svirret siden i mandags. Kapitulation, opbrud fra Danmark, rigsdagssamling, ny regering dannet o.s. v.?? Alt endnu usikkert, men det er tydeligt nok på vej efter Hitlers død og Berlins forestående fald. »Skriftlig udflugt $\star^{61}$ til Gal- 
lehus, guldhornstenene, vandmøllen, muntert kaffebord i kroen, bagefter hvil i den friske, nyudsprungne bøgeskov. Vi kom hjem kl. ca. 18,30. Kl. 19 luftalarm som næsten ustandseligt i den sidste tid. CB-erne er alarmeret og skal blive på deres poster $i$ nat, der ventes begivenheder, skal der virkelig kxmpes her? I mandags har de lelende embedsmænd på grevens kontor drøftet evakueringsplaner, forsyningssituation, lukningen af Ballum sluse og andre tilsyneladende defensive foranstaltninger. Kommer det nu? Kl.19,30 ser jeg lærer Poul Larsen, ${ }^{62}$ der har travlt, et rygte vil vide, at englæenderne ses syd for grænsen, han har med indkvartering at gøre og haster hjem. Kl. 20,30 afblæsning, vi hører Speers ${ }^{63}$ besynderlige tale over Flensborg radio, undertonen synes mig klar, kapitulationens forberedelse.

Fredag den 4. maj. Eksamen i regning. Ved frokosten minder jeg censor, amtsskolekonsulent Novrup ${ }^{64}$ om, at det snart kan være hans pligt at være på sin post og spørger, om man er rede til hurtig suspendering af de tyske lærere for at foregribe befolkningens selvtægt overfor dem.

Kl. 20,30: BBC melder om kapitulation og fred i nordvest. Vi sidder stumme og grebne, fatter det næppe, hører udsendelsen til ende som i drømme. Kl. 21,10 kommer et par elever: Skal vi ikke samles i læsesalen? Meget gerne. Jeg ringer rundt til lærerne. Kl. 21,30 er læsesal og borgestue fyldt af elever og lærere med familie, vi ophænger Dannebrog, det norske flag og et engelsk flag, der fremkalder dundrende bifald. Vi synger som den 9. april 1940: Alt står i "Guds faderhånd" —, jeg taler om krigen, der nu skal være forbi, om freden, der kommer, vi synger "Bladet $i$ bogen sig vender «, "Vi har et håb.« Tale og sang veksler, om fremtiden, om mălene, vi har kæmpet for, bekæmpelse af nazismen, også $i$ vore egne sind. »Det haver så nyligen regnet «. En gribende og enkel aften. 2 dages frihed, men morgensang lordag kl. 8.

Lordag den 5. maj. Gråvejr. Tidligt op, alle flag i orden. Kl. lidt i 8 vandrer alle elever og lærere fra læsesalen forbi lazaretfolk over til forstanderhaven. Vi mindes de faldne og synger "Guds fred med vore døde." Så begynder kirkeklokkerne at ringe, flaget glider op, og vi hilser kongen med "Kong Christian«. Morgensang i lresesalen. 
"Den signede dag." Kort morgenbøn, tak fordi vi har fået vort fædreland igen! „Fædreneland. « Friedy bringer en hilsen fra Schweiz.

Ved middagstid telefonisk meddelelse, at nogle englxndere kan ventes til Tønder. Vi iler til torvet, hvor en stor mengde venter. Kl. ca. 13 jubelråb fra Søndergade, så skimtes en engelsk flyver på skuldrene af begejstrede unge mennesker. Alle vifter med flag og råber, han bæres rundt på torvet under øredøvende råb, alle vil trykke ham $\mathrm{i}$ hånden, det lykkes at få ham over til rădhuset, hvor viceborgmester Jensen byder ham velkommen, og han siger et par ord. Hans kammerat er imens entret op på 1. sal i sparekassen, hvor han fotograferer det hele, dirigerer hurraråb og muntre opstillinger omkring flyveren. Endelig kommer han op på en vogn og køres ned til »Hotel Tønder «, alle følger med, Thomas får ham i hånden og hilser ham på engelsk, vi følges med fotografen til hotellet. Jeg smutter med ind og bliver opfordret til at hjxlpe som tolk sammen med Thorv. Petersen, viceborgmester og hr. Thiim. ${ }^{65}$ En times muntert samvær, englænderne fortæller, at de er pressefotografer, ude efter nyt, $\mathrm{i}$ morges vågnede de $\mathrm{i}$ Minden ved Hannover. Hvorhen $\mathrm{i}$ dag? Var der ikke noget om Danmark $i$ aftes $i$ radioen. Har vi benzin nok? Allright, vi tager til Danmark. Så fløj de herop. Hvor turde de lande her, så nær grænsen? Den største vanskelighed var at finde en mark uden alt for mange køer, i øvrigt tog folk jo meget venligt imod os, vi prøvede det også i Paris og Bruxelles, stemningen var den samme, men der var jo lidt flere! De făr suppe og et glas øl, så kommer borgmesteren til, jeg oversætter hans tale, så skal de afsted, vi følger dem over $\mathrm{i}$ borgmesterens lejlighed, fotografering på trappen, så ud til Stubkjær, hvor en lille Austermaskine står midt i marsken omgivet af køer og masser af nysgerrige mennesker. Kort efter starter de under jubelråb, slår en sløjfe over os og sætter kurs mod Minden/Hannover, "den største engelske flyveplads $i$ Tyskland “, som de sagde. En strålende oplevelse, så improviseret, xgte og barnlig glad, kønnere kan det ikke blive. Det var netop det udslag af vore hjerters strålende glæde, som vi alle trængte til at få. $\mathrm{Nu}$ har de været her, og selv om de kommer med trommer og piber, bliver det ikke festligere end dette øjeblik den 5. maj 1945!

Søndag den 6. maj. Pastor Magle ${ }^{66}$ kom hjem i aftes. Kl. 8,30 i dag takkegudstjeneste. Kirken stuvende fuld, mest greb mig synet af den 
fuldkommen afmagrede og elendige gartner Lorenzen, ${ }^{67}$ hjemvendt fra Neumünster, han lignede et lig midt $i$ kirken. Køn, hjertevarm prædiken af pastor Magle, der var noget forædlet og rent over ham efter de lange måneder i Frøslev. Vi besøger præstefamilien om eftermiddagen. Dagen ender $i$ regnvejr, der kom ikke flere englændere, og stemningen flover af, ikke mindst på grund af, at tre frihedskæmpere er blevet hårdt såret ved grænsen i går. Det vrimler med dem allevegne, de myldrer op af jorden, tilsyneladende meget kampberedte, men vistnok uden megen uddannelse. Der synes at være en del kompetencestrid mellem de kommunale myndigheder og modstandsbevægelsens byledelse, som vil råde enevældigt over det hele, men hvis repræsentanter ikke alle er lige imponerende eller dygtige.

Mandag den 7. maj. Jeg har lovet børnene en cykeltur, men da bilerne raser mod grænsen med officerer på flugt og varer, er jeg lidt betænkelig. Solen stråler, og vi vover det alligevel... og fortryder det ikke. På vejen til Sæd overhales vi af tre store tyske tanks. Og så står vi dernede ved det lille, hyggelige toldsted, hvor vi har stået så ofte under denne lange krig, vejviser $409 \mathrm{~km}$ til Frederikshavn; $i$ den seneste tid har tolderen, min ven, og jeg ofte sagt til hinanden, at nu er der længere til Frederikshavn end til englænderne, men det har lydt noget uvirkeligt. Her er adskillige frihedskæmpere i blå uniformer, de holder udkig op ad vejen mod nord og lægger sig skudklare i grøften, hver gang en bil nærmer sig. De fortæller, at der ventes en sort bil uden nummer med Hipofolk, og de har ordre til at skyde straks, hvis den ikke standser. Det lyder meget spændende, og der er også romantisk spænding over de unge mennesker, men nogen utilfredshed med de ret tilfældige og uklare ordrer, man sender dem. Et kompagni af cyklende ganske unge tyske soldater ruller forbi, enkelte forsøger et frækt grin og en bemærkning til frihedskæmperne, der udveksles et par mindre venlige replikker, men de ruller heldigvis uforstyrret over grænsen. Friedy og børnene går hen ad diget mod øst for at finde en plads, jeg bliver stående ved broen. $\mathrm{Da}$ kommer der to høje brune motorcyklister op sydfra, er det ungarere eller hvad, nej, nu ser jeg med store bogstaver på den forreste skærm R.A.F. og udstøder et brøl: "Det er englændere!! « De to høje mænd standser smilende: "Are we in Denmark!« Certain- 


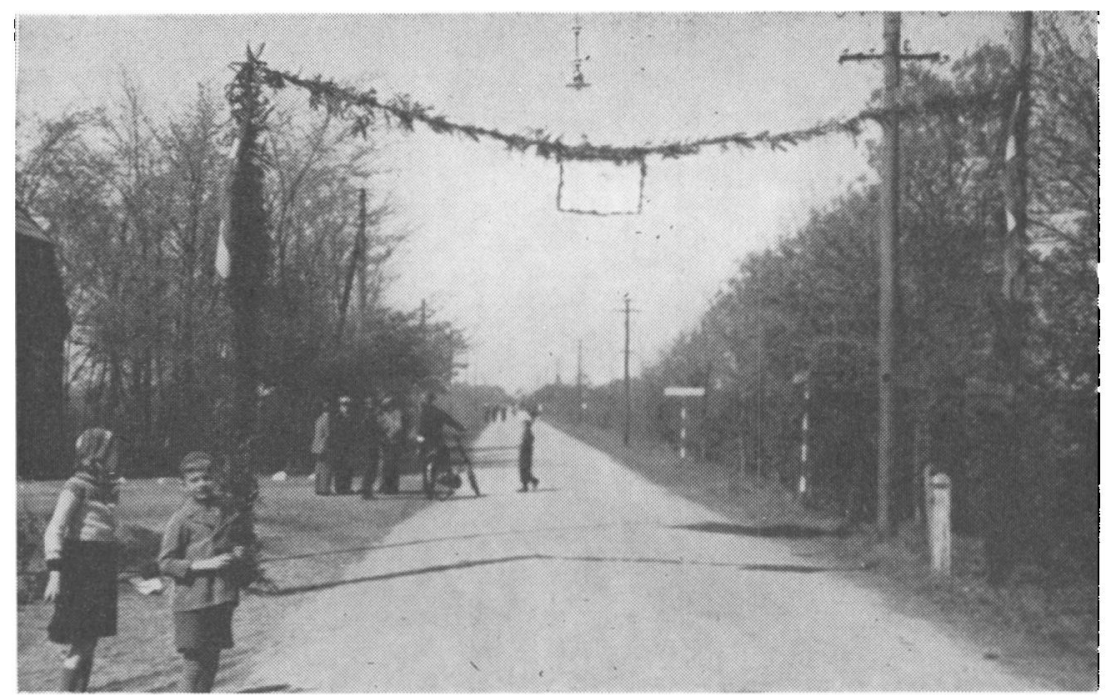

Granseovergangen ved Sad 7. maj 1945. Mod syd stod VELKOMMEN! (til englanderne), mod nord var vejene ud af landet trukket op!

ly, and you are the first to cross the frontier! « Jeg vinker efter familien, frihedskæmpere og toldere samles omkring dem, tolderen løber til telefonen for at melde dem til Tønder. Da ingen taler engelsk, holder jeg en lille begejstret tale, vi råber hurra af alle kræfter og synger "Der er et yndigt land « af fuld hals. Englenderne smiler og fortxller, at de skal op til en lille by ved grænsen, $5 \mathrm{~km}$ herfra, yes, Tøndern, og de ruller videre, men vi står helt betagne af glæde. Det var de første i Sæd, man havde ingen ventet i dag, og nu fik de denne beskedne, men meget hjertelige velkomst. Tolderen siger tak, fordi der dog blev sagt et par ord til dem. På xresporten ved broen har han skrevet Velkommen til Danmark, på bagsiden, der vender mod nord, er tegnet et Sønderjyllandskort, der viser hovedvejene ud af landet!

Om eftermiddagen samtale med pastor Nielsen, Højer, om de noget usikre forfatningsmæssige forhold under det noget diktatoriske frihedsråd, hvis leder $i$ Tønder mærkværdigvis er en person, hvem ingen nogensinde har taget alvorligt, næsten ingen sønderjyder med, $i$ det hele taget en ganske tilfældig gruppe, forekommer det os. Vi er lidt ængstelige for den selvtægt, som dette kan animere 
til, og håber snarest at se politiet klart i funktion. Ved aftensbordet meldes det, at englænderne kommer til byen i større tal. Smedegade fuld af tanks, 26 mand, der er parade på torvet, en engelsk officer holder en kort og klar tale om sin vanskelige opgave her, en komitémand byder velkommen, man glemmer helt at oversætte nogen af talerne, og det lidt tilfældige arrangement slutter med, at de køres til "Hotel Tønder «.

Tirsdag den 8. maj. Englænderne er i byen. Nu skal det gå løs! Det må være losenet, for fra tidlig morgen ruller lastbilerne gennem gaderne, udstyret med en politimand og 4-5 riffelbevæbonede mænd, arresterer hjemmetyskere og værnemagere, stikkere $\mathrm{m}$. $\mathrm{m}$. en bloc. Det ser drabeligt ud, minder rent ud sagt en smule om beskrivelser af begivenheder $i$ forbindelse med nazismens indtog i tyske og ostrigske byer før 1939, og om jødeforfølgelser. Det går meget ordentligt til, men hjemmetyskerne sidder aldeles forskræmte på bilerne, og ved deres ankomst til "Børsen" hujes der grimt og pøbelagtigt. Mon disse folk ikke alle var kommet af sig selv, hvis de havde fåte en almindelig arrestordre, dette her synes ikke strengt nødvendigt, men er på den anden side vel nok en uundgåelig udløsning. Jeg møder pastor Magle, vi er enige om at fordømme en gemen radioudsendelse $i$ aftes, en aldeles talentløs reportage af en stikkerarrestation $\mathrm{i}$ Kobenhavn, og jeg foreslär ham at sige et par ord. Han gør det, og han gør det fortræffeligt, henstiller til skrålhalsene på torvet at tie stille og vise kold foragt mod landsforrxdere, så kan de i øvrigt råbe et leve for Danmark!

Samme eftermiddag ser vi byens røde postbude vandre $i$ optog gennem byen med en pakkekærre, en stige, et brækjern og en harmonika. Under sang og musik sxtter de stigen til gadehjørnerne og brakker de overflødige tyske gadenavne ned, det er en virkelig fornøjelig idé, ${ }^{88}$ det er netop postbudene, der bør gøre dette. Hvordan skal tyskerne finde hjem $\mathrm{i}$ aften, spørger en (ironisk) bekymret sjel.

Onsdag den 9. maj. Friedy og fru Moltke har ordnet levnedsmidler til Flensborg, i dag skal vi afsted med $7^{3 / 4}$ tons. Vi kører kl. 13, men lige forinden erfarer jeg, at den ledende engelske officer er schweizer, jeg iler kl. 12 til hotellet, træffer ham og indbyder ham til varmt bad og middag $i$ aften, hvad han gerne tager imod. En stor dag! 


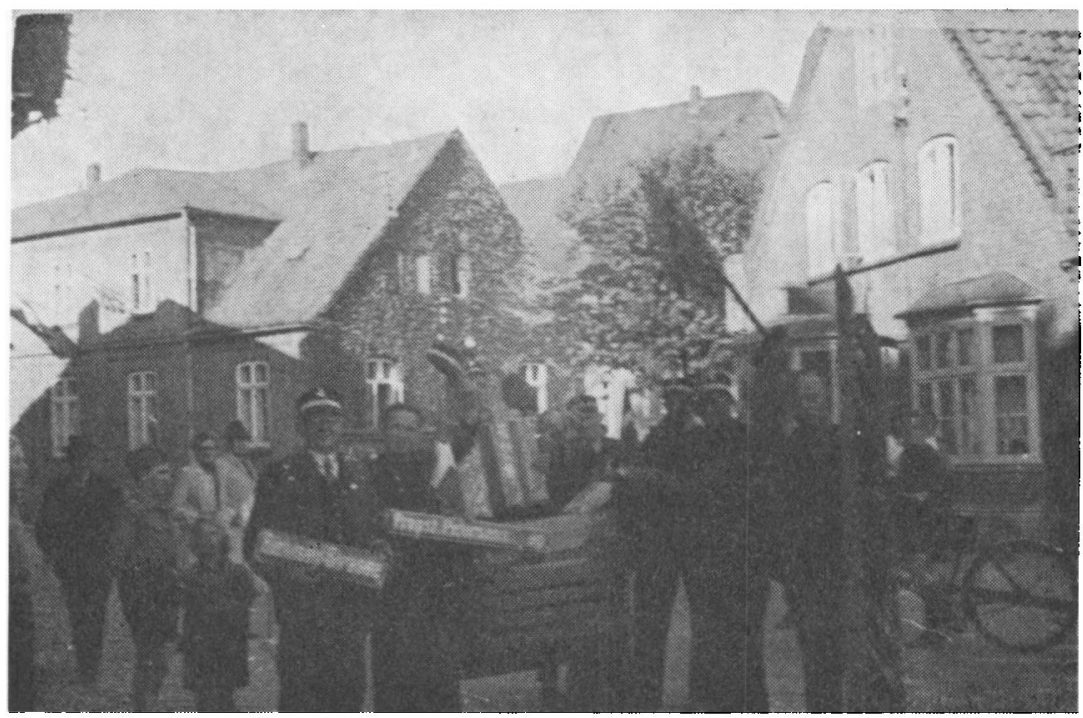

De danske postbude fjerner med musik de tyske gadeskilte $i$ Tonder 7. maj 1945.

Vi får kartofler i Rørkær, brød i Jejsing og når Krusaa kl. 14,30, der myldrer af mennesker, grænsen spærret af pigtråd og brigadefolk og frihedskæmpere. En brigademand tilbyder os hjælp, springer på vognen og standser os ved tolden. Det skulle han ikke have gjort. Toldmændene underkender ganske vore primitive papirer fra byledelsen i Tønder, hvor er Varedirektoratets tilladelse? "De kommer ikke over.»

Som supplement til dagbogsbladene folger ber

Beretning om den første levnedsmiddeltransport over grænsen, udarbejdet juni 1945.

Den 10. marts 1945 fejrede Tønder Husmoderforening den årlige fest med et foredrag af frk. Margrete Gudme, ${ }^{69}$ Flensborg. Efter forslag af et af bestyrelsens medlemmer, fru Frida Bredsdorff, havde medlemmerne medbragt hver en gave, fødevarer, klæder, fodtøj eller lign., som af en ung pige klædt i danske farver blev overrakt 
He. Snnimarieforstander Bredidonf hav Tilladelu hit

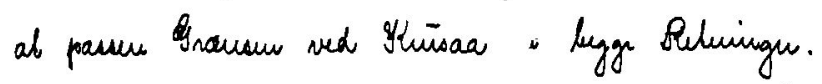

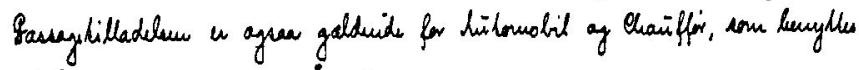

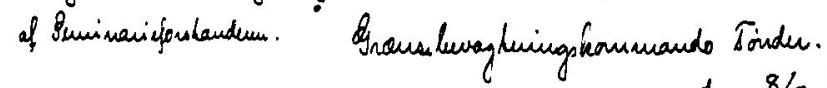

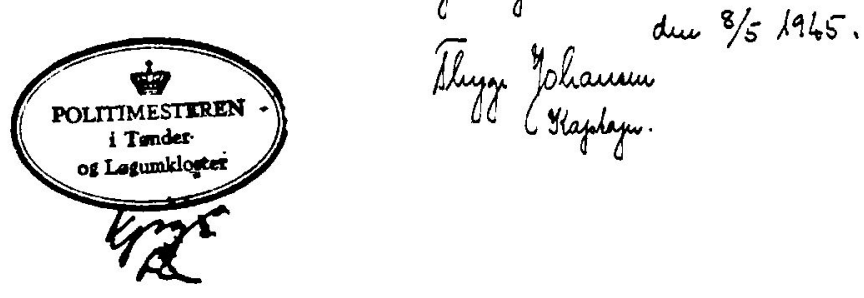

Grevinde Nolkte og Pru Forstander Bredsdorf harTilladelse til at passere Gränsen ved Slad med en Vognladning Pödevarer til Danske 1 Plensburg.

Med Laģtvognan fölger on Chauför.

Grevinde wolkte og Pru Foretander Bredadorf korer enten med Lastbilen eller 1 Passagervogn med Chaufför.

Tilladelsen gälder ogsan Hjemturen.

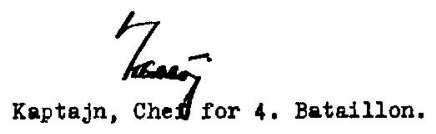

Tönder, den 15/5 1945.

Så enkelt kunne det altså gores.

frk. Gudme, der lovede at bringe gaverne til Flensborg og fordele dem mellem danske dernede. Da man næste dag ordnede gaverne, der omfattede alle mulige gode ting lige til stearinlys og tændstikker, ansloges de til ialt $1000 \mathrm{~kg}$. Det lykkedes frk. Gudme uden større vanskelighed at få disse gaver over grænsen. Tønder Husmoderforening udsendte herom en meddelelse til danske husmoderforeninger $i$ hele landet med opfordring til at indsamle mærker, og $i$ de følgende måneder lykkedes det ad forskellige veje at få fødevarer transporteret over grænsen. I begyndelsen af maj var man $i$ besiddelse af ret betydelige mængder rationeringsmærker og penge, 
desuden havde man fået løfte om hjælp fra Grænseforeningen, og ved befrielsen den 5. maj strømmede gaver ind. Man besluttede derfor at udnytte den midlertidigt åbnede grænse og de ret kaotiske forhold, som opstod. Lokalkomitéen i Tønder stillede på opfordring en stor lukket lastbil til rådighed, det lykkedes at skaffe passersedler på den overfyldte politistation - de var håndskrevne på stilebogspapir! - og onsdag den 9. maj kl. 13 rullede en stor lastbil ud af Tønder besat med grevinde Moltke og fru Bredsdorff, samt seminarieforstander Bredsdorff som hjælper; desuden fulgte redaktør Clausen, Vestslesvigs Tidende, med til Flensborg. På en gård i Rørkær hentede vi kartofler og flæsk, hos bageren i Jejsing lå 100 rugbrød parat, som vi kastede fra hånd til hånd ind $\mathrm{i}$ vognen. Så rullede vi ad Krusaa til, forbi løsrevne delinger og klumper af tyske soldater med trækvogne og rygsxkke fulde, delinger, der lå og hvilede i grøften. Kl. 14,45 nåede vi Krusaa mejeri, hvor der lå et par tons mel og gryn, som vi med nogle unge menneskers hjxlp fik slæbt ind $\mathrm{i}$ vognen. Her vrimlede med mennesker som ved et folkemøde, folk ventede sensationer. Brigadefolk og frihedskæmpere bevogtede grænsen, der var spærret med spanske ryttere, en brigademand sprang op på bilen og hjalp os ned til toldstedet, hvor vi desværre måtte gøre holdt. Her nægtede de, man ville vise vognen tilbage, i 5 kvarter stredes vi derom, jeg forsegte opringning til Varedirektoratet, forgæves, derefter talte jeg med den interimistiske grænsechef, dr. Jens Kruse, der lovede at hjælpe os over på den ene eller anden måde. Brigademanden tilbød at tvinge toldembedsmændene tilbage med sit skydevåben, hvad jeg dog henstillede at undlade, da vi har haft skyderi og tvang nok. Enden blev, at jeg måtte love at fremskaffe Varedirektoratets tilladelse, hvis ikke, ville det blive til en sag, og for at markere ulovligheden lod vi en bevæbnet brigademand for og bag ledsage vognen!

Først kl. 16,30 nåede vi »Flensborghus«, kørende gennem en strøm af soldater. Her ventede husmoderforeningens formand, fru journalist Jensen, menighedsplejens søster Helga og en del andre kvinder, spejderne hjalp med at danne spærring over fortovet, og så læssede vi af, så det kunne mærkes i ryggen i dagevis. Tyskere stod med fremstrakte hænder: Ist das nur für die Dänen? Ja!! Noget mel faldt i rendestenen, en hvidhåret mand kastede sig derover og skrabede det op i sin hue, born sprang efter en hoppende kartoffel, 4 udsul- 


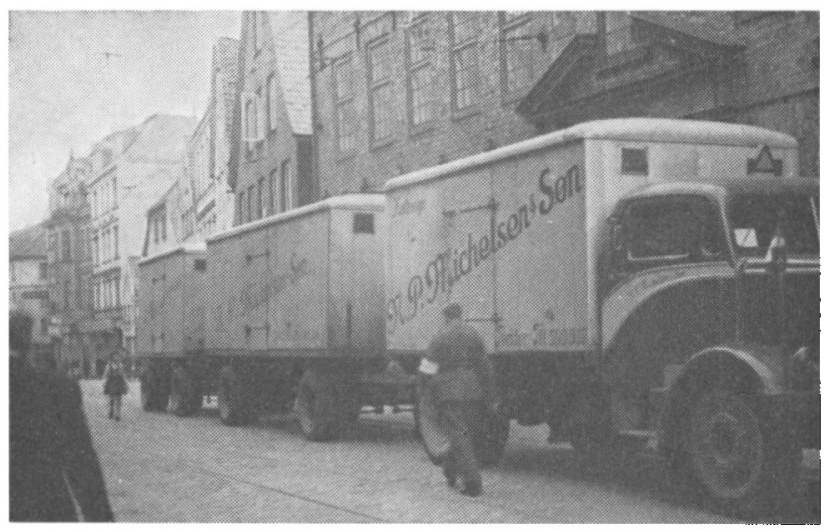

Vort vogntog ud for „Flensborghus" 9. maj 1945.

tede russiske kvinder trak vi ind $\mathrm{i}$ porten og gav dem hver et brød. Deres tak var rørende!

$P_{a}$ en god times tid var alt bragt $i$ hus med de mange hænders hjxlp, heriblandt to flinke brigademæend, ialt $7 \frac{1}{2}$ tons fødevarer. Stor glæde hos modtagerne, et glas øl i "Flensborghus«, og så afsted, ned gennem havnegaden, hvor politistationen var engelsk hovedkvarter, fjord og havn overfyldt af Østersø-dampere af enhver kategori, havnepladsen vrimlende af flygtninge og soldater, et vældigt billede af det opløste tredje rige. Så over grænsen og hjemme i Tønder kl. 18,45, hvor vi ventede den engelske kommandant, løjtnant Bertchinger til aften.

Det vellykkede forsøg opfordrede til gentagelse, så længe disse forhold varede. Gaver strømmede fremdeles ind fra mange sider, Danske Samfund i Tønder tilbød stor hjælp, og en ny tur blev planlagt til onsdag den 16. maj. Aftenen før læssedes med mange hænders hjzelp 3 store kølevogne, lastbiler kom ind fra omegnen, fødemidler af enhver art strømmede ind, ialt 17-18 tons. Det var lykkedes at få truffet aftale med lærer Lindstrøm, ${ }^{70}$ Ladelund, om, at han skulle møde os $\mathrm{i}$ Sønder Løgum og deltage $\mathrm{i}$ turen, ligesom vi af ham havde fået en liste over antallet af danske familier i sognene langs grænsen, så fordelingen kunne blive nogenlunde retfærdig. Toldinspektøren i Tønder skaffede os passerseddel for varerne, politimester Brix og det nu oprettede engelske grænsepoliti i Tønder 
udstedte pas, og onsdag den 16. maj kl. 9 startede toget fra Bachmanns mølle, hvor de sidste varer blev ladet ind. Brød og mel i første vogn, kød og konserves, samt $x g$ o. $1 . \mathrm{i}$ den anden, kartofler $\mathrm{i}$ den tredje.

Vi slap nemt over grænsen ved Sæd, udenom marchkolonner, og nåede Sdr. Løgum, hvor en dansk familie fik den første gode ration. For at undgå at skulle vende med det store vogntog blev Aventoft gemt til hjemturen. Derfra videre til Ladelund, hvor to hollandske krigsfanger hjalp med at losse varer ud og bxre dem op i forsamlingshuset, et stort arbejde. Her indbød lærer Lindstrøm os til middag. Turens deltagere var denne gang foruden de samme som sidste gang, lærerinde frk. Enemark, frk. Ingeborg Jacobsen ${ }^{71}$ og bagermester Th. Petersen. Derefter fulgtes vi med de to unge hollændere op til kirkegården og lagde en blomst på de 165 grave fra den nærliggende koncentrationslejr. Vi sang "Alt står i Guds faderhånd « Så gik turen til Valsbøl, hvor Kathrine Bojlesen ${ }^{72}$ tog imod, og nogle flygtninge hjalp med at bxre varerne ind. Stor taknemlighed, kartofler havde man ingen af, brød meget lidt, æg slet ikke. En hastig kop kaffe, og så videre til Langbjerg, hvor der kun var en kone hjemme ved det danske forsamlingshus. Heldigvis kom tre sultne russiske krigsfanger forbi, vi tilbød dem et brød, hvis de ville hjælpe. De hjalp af alle kræfter, slæbte sækkene ind og stablede dem op, og fik til sidst hver et brød og en pose kartofler, som de henrykt takkede for! En grædende russerkone bad for sine børn og fik lidt flæsk og et brød af fru Bredsdorff, hvem hun overøste med taksigelser. Derefter forbi den vældige flyveplads ved Hanved med masser af rustende flyvemaskiner af enhver art og størrelse til Harreslev. Her tog lærer Niels $\mathrm{Kjems}^{73}$ og hans kone imod os, her skulle læsses meget af til de godt 70 arbejderfamilier $i$ den danske koloni. 3 jugoslaviske krigsfanger tilbød deres hjælp, så det klaredes godt, alt blev stuvet ind $\mathrm{i}$ forsamlingshuset, ved et glas most droftede vi grænseproblemer, statsministeren $\mathrm{s}^{\mathbf{7 4}}$ udtalelse, den danske borgmester i Flensborg, og lyttede til Kjems' besindige ord. Vi beretter lidt fra Danmark og iler videre. Wehrmacht-police vil standse os uden for Flensborg, men vor ledsager i brigade-bilen, løjtnant Lund, hjælper os igennem.

Der var vrimlende fuldt af fodgængere på vejen til Slesvig, folk vil med os "Nach Hamburg «; vi vinker af og svinger ind foran den 
danske skole i Jaruplund. Her tager lærer Hans Eskildsen ${ }^{75}$ imod os, hele den danske koloni er samlet til kaffebord med ægte kaffe, engelsk te, amerikansk hvedebrød og fine kager, her har lige været engelsk indkvartering. Ved fælles hjælp får vi hurtigt læsset af, vi beretter ved kaffebordet om oplevelser i Danmark omkring befrielsen, frihedskæmpere og englændere. Hans Eskildsen taler lidt bittert om Buhls og Christmas Møllers udtalelser. "Christmas var vor bedste mand i 1920 «, siger en $x$ ldre kone. $\gg \mathrm{Nu}$ har han svigtet os. * Vi søger at forklare dem Danmarks vanskelige stilling, Englands og Ruslands modstridende interesser omkring Østersøen, Bornholms betydning, ønsket om at undgå nye irredenta, men stemningen er forståeligt nok noget nedslået. Stor glæde over gaverne, og så må vi afsted igen. Denne gang til Tarup skole, hvor lærer Damkjær Poulsen tager imod, varerne slæbes ind i skolestuen. Så iler vi til "Flensborghus «, hvor en stor skare kvinder og drenge er rede til at hjelpe os. Vi læsser løjtnant Lunds brigadebil med madvarer til de gamle på alderdomshjemmet i Lyksborg, hvor han kører hen, mens vi losser i „Flensborghus«. Et stort arbejde, her skal deponeres varer også til Slesvig og Tønning, vi stiller op $i$ en lang række, og så går brød, konserves, xgpakker, marmelade o. $\mathrm{m}$. a. fra hånd til hånd ind $\mathrm{i}$ salen. Inde i biblioteket får jeg en samtale med bibliotekar Momm$\operatorname{sen}^{76}$ og lærer Hans Meng ${ }^{77}$ om stillingen. De vil hjem, koste hvad det vil, tyskerne skal smides ud af Sydslesvig. Meng har været soldat 5-6 år, "vi har lært at være brutale", det er undertiden det bedste. Vi hilser på alle hjxlperne ved et glas øl på "Flensborghus«, de er glade ved at se en dansk brigademand. Så afsted igen kl. 19,30. Vi kører $\mathrm{i}$ den skyede aften ad landevejen lige syd for grænsen, standser ved krydset nord for Ladelund for at afsætte lærer Lindstrøm og aflæsse endnu en lille forsyning til ladelunderne ved den danske gård her. 2 unge piger og to franske krigsfanger, der endnu arbejder på gården, kommer ud og hjælper os. Da vi ruller afsted, ser vi dem slabe sxkkene ned mod gården. Kl. 20,30 er vi i Aventoft ude i den øde marsk, ad smalle veje og over broer når vi til Bøgh Andersens gård. De gamle folk bliver lykkelige, her på en bondegård har de ikke set kartofler siden februar. "Vi vanter dem hårdt «, siger de, og vi læsser de 20 sække af.

Under blasende aftenskyer losser vi de sidste varer herude $\mathrm{i}$ den lille ensomme landsby syd for Vidaaen, tyske børn og flygtninge 


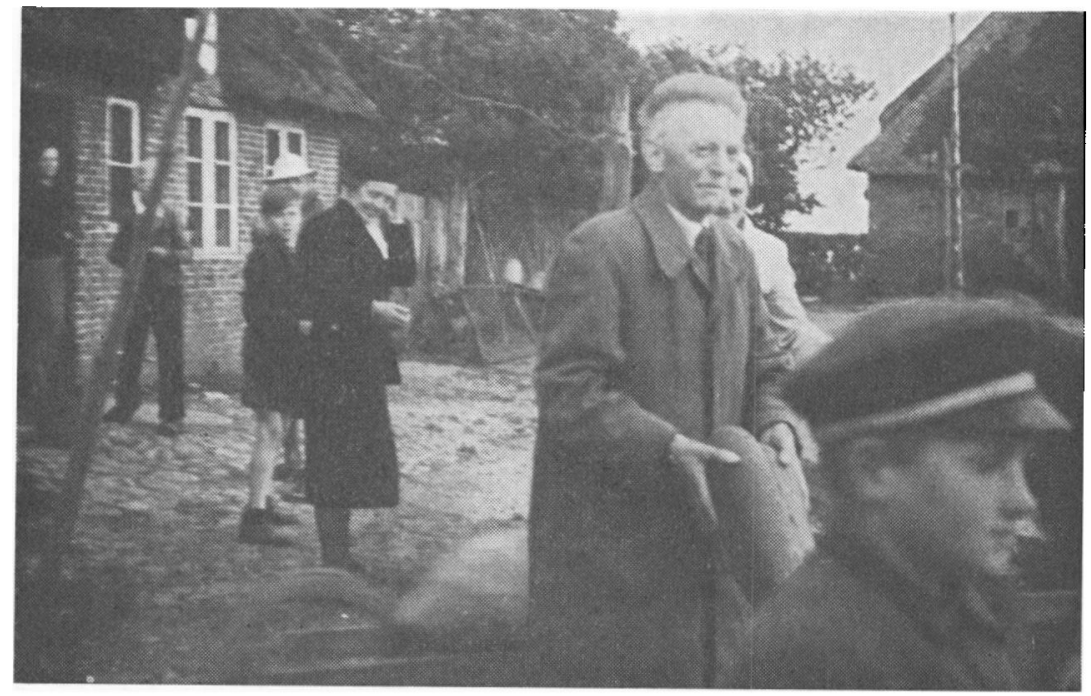

Brodudlevering $i$ Aventoft. I forgrunden bagermester Thorvald Petersen, delvis dakket af ham frk. Ingeborg Jacobsen og i baggrunden grevinde Helene Moltke.

hopper interesseret rundt om bilerne, de danske hjælpes ad og får med trillebør og håndkraft alt transporteret ind $\mathrm{i}$ gårdejer Bøgh Andersens lade. Så skal disse folk, som alle de øvrige steder, fordele så retfærdigt som muligt blandt de danske. Det bør nævnes, at vi på hjemvejen fra Flensborg blev standset af fru Kjems, Harreslev, der fortalte, at varerne allerede $i$ eftermiddagens og aftenens løb omtrent var blevet fordelt, idet de danske familier havde fået bud om hurtigst at komme og hente dem. Der var stor glæde og taknemlighed, hvad også et senere modtaget brev, underskrevet af alle danske i Harreslev, bekræftede. -

Så vender det store vogntog med besvær i Aventoft, vi sæetter kurs mod den spærrede Møllehusbro, og da den er bevogtet af danske brigadefolk, lykkes det let for løjtnant Lund at skaffe os fri passage. Inde ved Tønder har englænderne ganske vist spærret denne ikke tilladte vej med en stor lastbil på tværs af vejen, men ved at køre i grøften, slipper vi forbi. Kl. 22 er vi, trætte, men glade efter en bevæget og indholdsrig dag, atter $\mathrm{i}$ Tønder.

$\mathrm{Da}$ disse transporter herefter på grund af den skxrpede grænsespærring ikke længere lader sig gennemføre på denne måde, har man 
foreslået, at Danske Samfund overtager ledelsen, således at de fire sønderjyske amter - efter Claus Eskildsens forslag - hver sørger for en måneds forsyning ad gangen, nu med officiel tilladelse fra Varedirektoratet. Så kommer arbejdet ind $\mathrm{i}$ et fast spor.

Lørdag den 2. juni talte jeg efter indbydelse fra Flensborg Husmoderforening for 500 mennesker $i » F l e n s b o r g h u s \ll$, et gribende og festligt møde i teatersalen, bagefter kaffebord med taler og sang. Vor amerikanske ven, korporal René van Hasendonck, ${ }^{78}$ der kørte for os, deltog og blev hyldet af forsamlingen, der her for første gang fik luft for sine varme følelser for en allieret soldat, dem de ellers ikke kan hilse på eller tale med i den stramt militzrt regerede Flensborg by.

\section{NOTER OG HENVISNINGER}

1. Jørgen Jørgensen, f. 1888 , undervisningsminister 1935-42, indenrigsminister 1942-29. august 1943. Deltog på regeringens vegne $i$ Tender bys 700 års fest, (se dagbog 5. august 1943) sammen med departementschef J. Saurbrey.

2. Lensgreve O. D. Schack, Schackenborg, Møgeltønder, 1882-1949. Amtmand over Tender ame 1920-49.

3. Nicolai Svendsen, 1873-1966. Amtsskolekonsulent for Tonder amt 1920-46.

4. Jacob Randrup, f. 1884, rektor ved Tonder Statsskole 1930-54.

5. I besættelsesårene boede forstander Bredsdorff $i$ sommerferien med sin familie hos husmand Faurholm, Nalmose, Fynshav, på Als.

6. Fru Friedy Bredsdorff, f. Brack i Schweiz, 1897-1956.

7. Liselund, menighedsskole ved Slagelse, ledet af frimenighedspræsten Niels Dael.

8. T. Martensen-Larsen, f. 1893, politimester i Tønder 1934-43.

9. E. Brix, f. 1902, politimester i Tonder 1943-45.

10. H. H. Stegmann, 1884-1967, dommer i Tonder købstad m. v. 1937-54.

11. Tønder gennem Tiderne*, redigeret af M. Mackeprang, 1943. Skrifter, udgivne af Historisk Samfund for Sonderjylland nr. 3. Festskrift til byjubilæet.

12. Johan Paulsen, f. 1901, bankdirektør, Tønder Landmandsbank, borgmester i Tønder fra 1939.

13. P. O. Gläser, f. 1891, lærer ved Alexandrineskolen, den tyske kommuneskole $\mathrm{i}$ Tonder 1920-45. Medlem af Tønder byråd og menighedsråd til 1945.

14. Johannes Schmidt, 1869-1959, præst, folketingsmand 1920-39.

15. G. Rühmann, 1888-1960, præst for den tyske menighed i Tonder 1937-55.

16. C. Elholm, f. 1891, leder af den tyske mellemskole i Tønder 1924-39, skolekonsulent for de tyske skoler i Nordslesvig 1939-45, fmd. for den tyske lærerforening i Nordslesvig 1926-45.

17. S. B. Paludan-Müller, 1885-1944, oberst, chef for grænsegendarmeriet $1934-44$.

18. Orél, stor russisk industriby, syd for Moskva, som den tyske hær måtte rømme $\mathrm{i}$ begyndelsen af august 1943.

19. Erik Appel, 1880-1964. Domæneforpagter på Ellehus ved Jejsing i Tonder amt 1926-51. Medlem af Folketinget (V) 1939-50. 
20. Th. Claudi Westh, f. 1899, civilingeniør; leder af Statens Jordlovsudvalgs tekniske afdeling $\mathrm{i}$ Tønder. Fmd. for Tønder danske skolenævn 1940-46.

21. Claus Eskildsen, 1881-1947. Seminarielarer i Tønder 1909-47. Skolebogsforfatter, DDansk Grænselære^, 1936. Før 1920 medlem af Tønder byråd. Fmd. for Danske Samfund i Tonder by og omegn.

22. E. Brahm, f. 1902, skoleinspektor (overlærer) ved statsseminariets ovelsesskole fra 1941.

23. Thorvald Petersen, 1882-1955, bagermester i Tender, (*Vor Mager ), leder af det danske mindretal i Tonder for 1920. Byrådsmedlem fra 1919. Se Thorvald Petersen: Fra Als til Tonder, 1952.

24. Den 29. august 1943 trådte ministeriet Scavenius tilbage. Med henvisning til den tiltagende sabotage proklamerede den tyske værnemagt undtagelsestilstand $\mathrm{i}$ hele Danmark. Formelt blev alt samarbejde mellem danske myndigheder og besæettelsesmagten afbrudt. Reelt fortsatte de overste administrative chefer, støttet af politikerne, med at føre den civile administration videre indtil 1945. Dette * departementchefstyre indsatte i Jylland amtmand Herschend, Vejle, som overste civile leder af den danske administration på den jyske halvø. Han fik hovedkontor i Silkeborg og skulle bistå danske embedsmand og andre danske borgere over for den tyske værnemagt.

Se N. Alkil: Besættelsestidens fakta, 2. bind, 1945-46.

25. A. Gravgaard, f. 1908, seminarielærer i Tonder 1938-52.

26. Hans Magle, f. 1891, sognepræest for den danske menighed i Tønder 1937-58.

27. Hans Andersen, f. 1886, gårdejer, Kongsbjerg. Fmd. for Landevæernet 192763 og for De sønderjydske danske Samfund 1940-58.

28. Dr. Dahl, f. 1898, læge i Tønder, af tyskerne beskyldt for at være medlem af det kommunistiske parti.

29. Poul Schülein, 1883-1952, Løgumkloster, provst i Tønder provsti.

30. Helene Moltke, f. 1906, datter af bagermester Thorvald Petersen, (note 23), larerinde ved ovelsesskolen, gift med oberst i grænsegendarmeriet, greve Aage Moltke.

31. Carsten Eskildsen, f. 1916, søn af Claus Eskildsen (note 21), lærer ved øvelsesskolen.

32. Kirsten Horsbel, f. 1906, lærerinde ved seminariet fra 1930.

33. Frede Hansen, f. 1897, lektor ved seminariet 1941-67.

34. Niels Moller, 1885-1958, dr. phil., lektor ved seminariet 1938-52.

35. Aage Rahr, 1888-1948, mag. art., lektor ved seminariet 1920-48.

36. H. Lausten-Thomsen, 1878-1958, amtslæge i Tønder, skolelæge ved ovelsesskolen fra 1926.

37. Jens Moller, 1894-1951. Overdyrlage, partifører for NSDAP fra 1935, -folkegruppefører* fra 1938, folketingsmand 1939-43.

38. S. C. Brejl, 1893-1964, viceinspektør ved øvelsesskolen i Tønder, amtsskolekonsulent $\mathrm{i}$ Tonder amt 1946-1964.

39. Finlandshjælpen blev oprettet under den finsk-russiske vinterkrig 193940 for at hjælpe finske born fra de krigshærgede egne. Bredsdorff var formand for Finlandshjælpen $\mathrm{i}$ Tonder amt, hvor den finske lotte, fru Anita Roos, Helsinki, førte tilsyn med finske børn i hjemmene $i$ Vestslesvig. Under den anden finske krig 1943-44 genoprog Finlandshjelpen arbejdet med at bringe finske born, især fra det besatte Karelen, til Danmark. 
40. Den 2. oktober 1943 udstedte den tyske værnemagt fra København officiel *Mcddelelse om jødernes fjernelse $\mathrm{i}$ forbindelse med forsøgsvis løsladelse af internerede danske soldater*. Her beskyldtes de danske jeder for *deres tyskfjendtlige ophidselsesvirksomhed og deres materielle og moralske støtte til terror og sabotagehandlinger $*$. Se Besættelsestidens fakta, 2.

41. Jakob Petersen, 1884-1952, bibliotekar i Ảbenrå, fmd. for Sprogforeningen fra 1936-52.

42. Hans Schmidt, Kollund, f. 1885, gårdejer.

43. Johs. Juhl, Branderup, 1886-1960. Fmd. for Senderjysk Idrætsforening 1920-49.

44. Lærer G. var den tyske larer P. O. Gläser (note 13).

45. Lærer E. var den daværende lærer ved det tysksprogede Tønder Seminarium Claus Eskildsen (note 21). $* \mathrm{Vi}$ [der danske mindretal i Tønder før 1920] har altid haft tillid til Claus Eskildsen og glemmer ham ikke, at han $i$ december 1909 under $\rightarrow$ Stormen på Tønder * [et altysk propagandamøde] en mørk aften i Nørreallé gav [redaktør] Skovrøy et stenograferet referat af dr. Hahns tale, som vi ellers ikke kunne komme $i$ besiddelse af. Eskildsen var medlem af Tonder byråd....*

Thorvald Petersen: Fra Als til Tønder, Skrifter udgivne af Historisk Samfund for Sønderjylland, nr. 13, 1952, side 132-133.

46. J. Utoft, f. 1908, seminarielarer $\mathrm{i}$ Tønder 1933-49.

47. A. H. Glenstrup, f. 1911, seminarielærer i Tonder 1937-52.

48. Helligåndshuset, det gamle vajsenhus, sencre alderdomshjem, i Østergade, i 1938 erhvervet af Tonder Statsseminarium, ombygget og indrettet til bibliotek, læsesal, praktikklasse, samt tjensteboliger for overlærer og pedel.

49. N. P. Nielsen, f. 1885, kapellan i Højer 1933-43 og tillige præst i grænsesognene (Burkal, Hostrup m. fl.). Fra 1943-52 sogneprest for den danske menighed i Højer, 1944/45, mens pastor $H$. Magle (note 26) var interneret i Frøslevlejren, tillige prest for den danske menighed $i$ Tønder.

50. P. H. Lundsteen, f. 1910 , cand. jur. $1943-45$ tilforordnet amtmand P. Herschend, det jyske hovedkvarter i Silkeborg (se note 24). 1960 amtmand over Maribo amt.

51. Harald Bredsdorff, f. 1902, sognepræst i Magleby, Stevns, var i april 1945 en kort tid arresteret af tyskerne.

52. Bagermester Svend Petersen 1911-1954, søn af $\times$ Vor Bager*, Thorvald Petersen, Tonder.

53. DKB var $\gg$ Danske Kvinders Beredskab*, en humanitær hjælpeorganisation under besæettelsen.

54. Inger Enemark, f. 1897, lærerinde ved Tønder Statsseminarium.

55. I oktober 1944 blev 5 seminarieelever arresteret af tyskerne efter et sabotageforsøg på banegården Tønder Øst. I januar 1945 blev de fra Frøslevlejren transporteret til koncentrationslejren Neuengamme ved Hamburg, hvorfra de alle vendte hjem $i$ foråret 1945 , flere af dem svart medtagne. Se *Mens vi ventede -«, Folkeskolen under besættelsen, 1946, side 196.

56. Ernst Kiørboe, f. 1883, lektor ved Tønder Statsskole, 1920-1953.

57. Carla Schibler, 1895-1965. Vandrelærerinde i Rudbøl og St. Jyndevad 1937-41. Arbejdede derefter for Sønderjydsk Idrætsforening til 1945. 1951 leder af ungdomsskolen i Hojer.

58. Olga Reppien, f. 1898, forstanderinde for husholdningsskolen i Gråsten fra 1933. 
59. „En svensker er grev Folke Bernadotte, der i februar-april 1945 iværksatte Røde Kors-transporter af danske og norske fanger fra tyske koncentrationslejre til Danmark og Sverige og efterhånden formåede at befri et voksende antal fanger fra andre besatte lande. Se ${ }^{\circ}$ Count Folke Bernadotte* by $\mathrm{R}$. Hewins, London, 1948.

60. San Francisco-konferencen april-juni 1945 vedtog $\mathrm{p}^{2}$ de sejrende magters vegne Forenede Nationers Pagt.

61. Skriftlig udflugt*, en gammel tendertradition, var en fælles udflugt til fods for hele statsseminariet dagen efter lærerexamens skriftlige prover.

62. Poul Larsen, 1911-1966, laerer ved statsseminariets øvelsesskole.

63. Albert Speer, nazistisk rustningsminister, vendte sig i 1945 mod Hitler. Ved Nürnbergdomstolen idømt 20 års fængsel.

64. Hans Novrup, f. 1889, amtsskolekonsulent i Åbenrå-Sønderborg amter 1937-59.

65. N. J. Thiim, f. 1904, lærer ved ovelsesskolen i Tønder.

66. Pastor Hans Magle sad i 1944/45 som fange i Froslevlejren.

67. Gartner J. Lorentzen, f. 1894, Tonder, vendte i maj 1945 hjem fra langvarigt ophold i tysk koncentrationslejr.

68. Fra genforeningen 1920 til 8. maj 1945 var gaderne $\mathrm{i}$ Tønder forsynet med

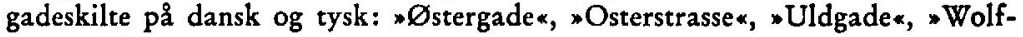
strasse (!) osv.

69. Margrethe Gudme, 1895-1946 KFUK-sekretær i Flensborg.

70. Gustav Lindstrøm, 1896-1965, vandrelærer i Sydslesvig 1921-1962, bosat i Ladelund.

71. Ingeborg Jacobsen, f. $1897 \mathrm{i}$ Lendemark, indehaver af en forretning med bl. a. Tonderkniplinger på Storegade $\mathrm{i}$ Tonder.

72. Kathrine Bojlesen, 1891-1945 vandrelærerinde og medhjælper hos den danske sygeplejerske i Valsbøl, Maren Sørensen.

73. Niels Kjems, født 1888, vandrelærer i Sydslesvig 1922-1957, bosat i Harreslev.

74. Ved Rigsdagens åbning den 5. maj 1945 sagde statsminister V. Buhl på samlingsregeringens vegne: Grænsen ligger fast! Udenrigsminister Christmas Moller gav udtryk for samme holdning.

75. Hans Peter Eskildsen, f. 1905, sen af Claus Eskildsen, lærer ved den danske privatskole i Jaruplund, 1933-46.

76. Frederik Mommsen, 1901-65, leder af det danske bibliotek på Flensborghus $*$.

77. Hans Meng, 1901-1954, leder af skolen ved Friserbjerget i Flensborg 193145. I tysk krigstjeneste 1939-45. Ved sin død vicedirektør i Dansk Skoleforening for Sydslesvig.

78. René van Hasendonck, belgisk-amerikaner fra California, USA, meldte sig efter Belgiens erobring i 1940 som frivillig soldat i den britiske hær. I majjuni 1945 var han indkvarteret hos familien Bredsdorff $i$ Tonder. 